(C) Cambridge University Press 2018. This is an Open Access article, distributed under the terms of the Creative Commons Attribution licence (http://creativecommons.org/licenses/by/4.0/), which permits unrestricted re-use, distribution, and reproduction in any medium, provided the original work is properly cited.

\title{
Cassava whitefly, Bemisia tabaci (Gennadius) (Hemiptera: Aleyrodidae) in East African farming landscapes: a review of the factors determining abundance
}

S. Macfadyen ${ }^{1 *}$, C. Paull $^{2}$, L.M. Boykin ${ }^{3}$, P. De Barro ${ }^{2}$, M.N. Maruthi ${ }^{4}$, M. Otim ${ }^{5}$, A. Kalyebi ${ }^{5,6}$, D.G. Vassão ${ }^{7}$, P. Sseruwagi ${ }^{6}$, W.T. Tay ${ }^{2}$, H. Delatte ${ }^{8}$, Z. Seguni $^{6}$, J. Colvin $^{4}$ and C.A. Omongo ${ }^{5}$

${ }^{1}$ CSIRO, Clunies Ross St. Acton, ACT, 2601, Australia: ${ }^{2}$ CSIRO, Boggo Rd. Dutton Park, QLD, 4001, Australia: ${ }^{3}$ University of Western Australia, School of Molecular Sciences, 35 Stirling Highway, Crawley, WA 6009, Australia: ${ }^{4}$ Natural Resources Institute, University of Greenwich, Chatham Maritime, Kent, ME4 4TB, UK: ${ }^{5}$ National Crops Resources Research Institute, Kampala, Uganda: ${ }^{6}$ Mikocheni Agricultural Research Institute, P.O. Box 6226 Dar es Salaam, Tanzania: ${ }^{7}$ Max Planck Institute for Chemical Ecology, Hans-Knoell Str. 8 D-07745 Jena, Germany: ${ }^{8}$ CIRAD, UMR PVBMT, Saint Pierre, La Réunion 97410-F, France

\begin{abstract}
Bemisia tabaci (Gennadius) (Hemiptera: Aleyrodidae) is a pest species complex that causes widespread damage to cassava, a staple food crop for millions of households in East Africa. Species in the complex cause direct feeding damage to cassava and are the vectors of multiple plant viruses. Whilst significant work has gone into developing virus-resistant cassava cultivars, there has been little research effort aimed at understanding the ecology of these insect vectors. Here we assess critically the knowledge base relating to factors that may lead to high population densities of sub-Saharan African (SSA) B. tabaci species in cassava production landscapes of East Africa. We focus first on empirical studies that have examined biotic or abiotic factors that may lead to high populations. We then identify knowledge gaps that need to be filled to deliver sustainable management solutions. We found that whilst many hypotheses have been put forward to explain the increases in abundance witnessed since the early 1990s, there are little published data and these tend to have been collected in a piecemeal manner. The most critical knowledge gaps identified were: (i) understanding how cassava cultivars and alternative host plants impact population dynamics and natural enemies; (ii) the impact of natural enemies in terms of reducing the frequency of outbreaks and (iii) the use and management of insecticides to delay the development of resistance. In addition, there are several fundamental methodologies that need to be developed and deployed in East Africa to address some of the more challenging knowledge gaps.
\end{abstract}

Keywords: cassava, ecology, natural enemies, climate change, cultivars

(Accepted 28 December 2017; First published online 13 February 2018)

*Author for correspondence

Phone: +61 (02) 62464432

Fax: +61 (02) 62464094

E-mail: Sarina.Macfadyen@csiro.au 


\section{Introduction}

Bemisia tabaci (Gennadius) (Hemiptera: Aleyrodidae) is a pest species complex that causes widespread damage to cassava, a staple food crop in many millions of smallholder households in Africa (Otim-Nape et al., 2000; Colvin et al., 2004; Legg et al., 2006; Patil et al., 2015). Bemisia tabaci causes direct feeding damage to cassava, excretes a sugar-rich honeydew, which acts as a substrate for sooty moulds that reduces both respiration and photosynthesis (Nelson, 2008). In addition, B. tabaci vector multiples plant viruses that cause two damaging diseases: cassava mosaic disease (CMD) and cassava brown streak disease (CBSD), that in combination lead to significant yield loss in cassava (Holt \& Colvin, 2001; Maruthi et al., 2002a, b). Whilst substantial effort has gone into developing virus-resistant cassava cultivars, there has been little research effort aimed at understanding this insect vector, which alone can reduce yields, by $40 \%$ (Thresh et al., 1997). This disproportionate approach to managing insectvectored plant diseases is not unusual, but has led repeatedly to management solutions that are not sustainable. Based on partial mtCO1 gene sequence phylogenetic analysis, the $B$. $t a-$ baci complex is composed of four major clades (a clade is a group of organisms believed to have all descended from a common ancestor). The sub-Saharan Africa (SSA) clade forms the ancestral root (Boykin et al., 2013) of the complex, and in recent history, species in this clade have been associated with an increased frequency of cassava viral disease outbreaks in East Africa. This review of the empirical evidence is timely and necessary as we need to identify clearly the biotic and abiotic factors that may have contributed to high population growth of $B$. tabaci in the past, before we can develop urgently needed and sustainable management recommendations for the future.

Whilst many hypotheses have been put forward about the factors that may be contributing to high $B$. tabaci populations on cassava in East Africa, there are little data available and these tend to have been collected in a piecemeal manner.

Our objectives for this review are firstly, to synthesize the existing literature on the SSA B. tabaci species' ecology in East Africa and to review critically this knowledge base. We focused on empirical studies that have examined factors that may lead to high populations or outbreaks of the SSA B. tabaci. We then identified the gaps in knowledge and understanding that need to be filled to deliver long-term sustainable solutions to manage both the vector species and the viruses that they transmit. We started by listing factors that, from an a priori perspective, are likely to be important ecological determinants of B. tabaci abundance (table 1) in any farming context. Factors that may support or limit population growth were equally considered (as these both may facilitate outbreaks). We then searched for studies based in East African production landscapes, preferring those focused on cassava. We included the countries of Tanzania, Uganda, Rwanda, Burundi, South Sudan and Malawi as part of the geographical region of Eastern Africa. In cases where we could not find published studies based in East Africa, we cited geographically related work if relevant. We excluded studies that look solely at virus impacts on the crop, and there have been several important review articles that have summarized information on cassava virus disease epidemics and speculated on some of the likely causes (table 2). In addition, there are reviews by Fishpool \& Burban (1994); Legg (1994) and Colvin et al. (2006) that provide a good baseline of ecological and biological information on what was known about $B$. tabaci complex and cassava viruses up until the late 1990s. A complicating factor in reviewing the evidence base for factors relating to East African B. tabaci is that our understanding of $B$. tabaci as a species has changed in the previous decade and so it is at times unclear as to the actual identity (as determined by their partial mtCO1 gene sequence) of the species being referred to, especially in older references. Where possible, we attempted to resolve these issues.

\section{African B. tabaci species complex: naming and identification}

Throughout this review, we use B. tabaci to mean the B. $t a-$ baci species complex found in East Africa. However, the identification of the species involved in these outbreaks based on genetic differences has only recently been attempted (see example from Kenya in Manani et al., 2017). Due to morphological similarities, $B$. tabaci was originally thought to be one species worldwide, but based on genetic differences (Colvin et al., 2004; Sseruwagi et al., 2005; Boykin et al., 2007; 2013; Wang et al., 2014); and mating incompatibility (Colvin et al., 2004; Xu et al., 2010; Liu et al., 2012), it is now recognized as a species complex with at least 34-36 species (Boykin et al., 2012; Barbosa et al., 2015). This discovery of further species diversity has led to many nomenclatural changes over the last 10 years causing confusion in the literature (Boykin \& De Barro, 2014; Boykin et al., 2018).

The SSA B. tabaci species are no exception to the nomenclatural confusion. Identification of species in the $B$. tabaci pest complex currently relies on the $3^{\prime}$ region of $657 \mathrm{bp}$ partial mtDNA COI gene identity. However, many names have been used for the same SSA entities with little consistency from study to study. The naming confusion has made it difficult to compare studies of ecological importance across time or from different researchers. For example, Sseruwagi (2005) used 'Ug1', Legg et al. (2014a) used 'SSA1 subgroups 1-3' and Mugerwa et al. (2012) used 'SSA1 subclades I-III' based on mtCO1 data. Are these the same entity? In short, no. Relevant to this study are the SSA1 and SSA 2 species of B. tabaci, where Ug1 = SSA1 and further subdivisions of that species include SSA1 subgroup 1 (Legg et al., 2014a) = SSA1 subclade I (Mugerwa et al., 2012). However, Ug2 (Sseruwagi et al., 2005) translates directly to SSA2 (Mugerwa et al., 2012; Legg et al., 2014a) with little confusion. Most of the confusion involves the SSA1 species, because most studies did not compare their SSA1 mtCO1 sequences against the then known available diversity. This meant that their data were not set firmly within a complete understanding of $B$. tabaci diversity at the time (Boykin et al., 2018).

Greater clarity around the species identity of individuals involved in future outbreaks may help to uncover the causes of these outbreaks. Even closely related species may differ in their host-plant use, ability to transmit viruses, fecundity and response to management actions. Conclusions and findings from past work in this region, however, are still useful to understanding the ecology of the species complex. In addition, species-specific management strategies and interventions could play a larger role in the future (see 'Knowledge gaps' section towards the end of this review).

\section{Overview of the life cycle of B. tabaci}

The life-history parameters of many species in the B. tabaci complex vary depending on the environmental conditions and 
Table 1. Potential factors influencing Bemisia tabaci abundance on cassava included in this review (does not include interactions between these factors). We have suggested the likely direction of the effect in terms of an increase $(\uparrow)$ or decrease $(\downarrow)$ in B. tabaci abundance, but note there are many possible outcomes for some of these factors.

\begin{tabular}{|c|c|c|}
\hline Factors & Potential mechanisms that may lead to a change in abundance & Likely direction of effect \\
\hline Cassava cultivar & $\begin{array}{l}\text { Leaf architecture (e.g. width of leaves) } \\
\text { Growth habit (e.g. long vs. short growing season) } \\
\text { Plant chemistry differences between cultivars }\end{array}$ & $\begin{array}{l}\text { Wider leaves }=\uparrow \text { nymph density } \\
\uparrow \text { Up to } \sim 6 \text { months after planting, then steady } \downarrow \text {. Exact cause } \\
\text { unknown } \\
\text { Unknown - depends on compounds involved }\end{array}$ \\
\hline Cassava age & $\begin{array}{l}\text { Number of new leaves at the top of the plant } \\
\text { Change in plant chemistry as cassava ages }\end{array}$ & $\begin{array}{l}\text { More new leaves }=\uparrow \text { adult density } \\
\text { Unknown }- \text { depends on compounds involved }\end{array}$ \\
\hline Infection status of cassava & $\begin{array}{l}\text { Fecundity and survivorship enhanced on infected hosts } \\
\text { Promotion of emigration of } B \text {. tabaci adults }\end{array}$ & $\begin{array}{l}\uparrow \text { Adult and nymph density on cassava plants } \\
\text { Unknown - may increase populations, but also spread densities }\end{array}$ \\
\hline Non-cassava host plants & $\begin{array}{l}\text { Other crops, natural vegetation and weeds act as host plants for } \\
\text { B. tabaci }\end{array}$ & $\begin{array}{l}\uparrow \text { Population density in cassava if more resources present in } \\
\text { landscape year-round }\end{array}$ \\
\hline $\begin{array}{l}\text { Spatial arrangement and amount of host plants } \\
\text { surrounding cassava fields }\end{array}$ & $\begin{array}{l}\text { More resources for } B \text {. tabaci at important times } \\
\text { More resources for natural enemies }\end{array}$ & $\begin{array}{l}\uparrow \text { Population density in cassava if more resources present in } \\
\text { landscape year-round } \\
\downarrow \text { Population density in cassava if more resources for natural } \\
\text { enemies present in landscape year-round }\end{array}$ \\
\hline Natural enemies & $\begin{array}{l}\text { Predators consuming } B \text {. tabaci } \\
\text { Parasitoids using } B \text {. tabaci as host }\end{array}$ & $\begin{array}{l}\downarrow \text { Nymph density from increased mortality due to natural enemies } \\
\text { Unknown - intra-guild predation effects }\end{array}$ \\
\hline Other pests on cassava & $\begin{array}{l}\text { Cassava green mite damage to top leaves. Reduces suitable } \\
\text { space on plant for } B \text {. tabaci adults }\end{array}$ & $\begin{array}{l}\downarrow \text { Adult density on top leaves may lead to reduced oviposition } \\
\text { Unknown - synergistic effects of multiple pests overcoming } \\
\text { host-plant defences }\end{array}$ \\
\hline Endosymbionts & $\begin{array}{l}\text { Presence of some endosymbiont species in } B \text {. tabaci can } \\
\text { decrease the number of adults emerging, increase } \\
\text { development time, thus reducing overall population } \\
\text { development }\end{array}$ & $\begin{array}{l}\downarrow \text { Healthy adult emergence rate } \\
\downarrow \text { Population density in landscape }\end{array}$ \\
\hline Altitude & $\begin{array}{l}\text { Unclear, combination of temperature, rainfall and host-plant } \\
\text { availability. Less suitable conditions at higher altitudes }\end{array}$ & Unknown \\
\hline Climate & Long-term changes in temperature and rainfall & Unknown \\
\hline Weather & $\begin{array}{l}\text { Heavy rainfall events } \\
\text { Very high temperatures }\end{array}$ & $\begin{array}{l}\downarrow \text { Nymph density, through increasing mortality due to heat stress } \\
\text { and dislodgement } \\
\downarrow \text { Population density perhaps through disrupting adult behaviour }\end{array}$ \\
\hline Pesticides & $\begin{array}{l}\text { Resistance in B. tabaci } \\
\text { Pesticides killing natural enemies or competitors }\end{array}$ & $\uparrow$ Population density in landscape \\
\hline New invasive species in East Africa & $\begin{array}{l}\text { Totally new species has taken over from local species in cassava } \\
\text { (species turnover) }\end{array}$ & $\begin{array}{l}\text { Unknown. It is unclear how this would lead to a change in } \\
\text { abundance in isolation from other factors }\end{array}$ \\
\hline Hybridization & $\begin{array}{l}\text { 'Invader biotype' out-competes domestic species and is better } \\
\text { able to use resources }\end{array}$ & $\begin{array}{l}\text { Unknown. It is unclear how this would lead to a change in } \\
\text { abundance in isolation from other factors }\end{array}$ \\
\hline
\end{tabular}


Table 2. Review articles with relevant information about Bemisia tabaci biology and ecology.

\begin{tabular}{ll}
\hline Citation & Topics covered \\
\hline Legg et al. (2014b) & Historical account of virus outbreaks \\
& Emergence of 'superabundant' B. tabaci \\
& Control options for B. tabaci \\
Legg et al. (2011) & Regional epidemiology of cassava virus pandemics across Africa \\
& Comparison of characteristics of CMD and CBSD outbreaks \\
Patil \& Fauquet (2010) & Very comprehensive review of the cassava viruses \\
& CMD dynamics in East Africa \\
Legg \& Thresh (2000) & Mechanisms behind the spread of the CMD pandemic \\
& Describes the pandemic of CMD across east and central Africa \\
Legg (1999) & Strategies to control the pandemic \\
& B. tabaci and CMD in Africa \\
Otim-Nape et al. (1995) & Very comprehensive treatment of all aspects of the disease and vector story \\
& Biology of B. tabaci including morphology, taxonomy, bionomics \\
Fishpool \& Burban (1994) & Ecology on cassava in Africa \\
& Some discussion about natural enemies and control \\
Legg (1994) & Ecology of whitefly and CMBs pathosystem \\
& Factors affecting population development of B. tabaci; temperature, climate, rainfall, host-plant \\
& chemistry, architecture and age, natural enemies \\
& Interactions between B. tabaci and other cassava pests
\end{tabular}

CMBs, cassava mosaic begomoviruses; CMD, cassava mosaic disease; CBSD, cassava brown streak disease.

the host plant they develop on. The published information suggests that the development period of $B$. tabaci from egg to adult emergence is between 19 and 29 days, and the species goes through four nymphal instars before entering a pupal phase (Colvin et al., 2006). Depending on the environmental conditions, there can be 11-12 generations of $B$. tabaci per year (Asiimwe et al., 2007a; b). In East Africa, cassava is planted from cuttings twice per year in some parts of Uganda, through to one cropping season in Malawi. Depending on the cultivar used, the plant can remain in the ground for 6-12 months before the tuber is ready to be harvested. Often, cassava is planted in a mixed field with maize, coffee and banana, and multiple cassava fields of different ages can exist in one location, providing year-round host plants for B. tabaci. A description of the different developmental stages of $B$. tabaci on cassava, using a colony established in Uganda, is presented in Thompson (2000). Adult female B. tabaci produce $4-5$ eggs per day and these are oviposited on the underside of the leaves and the leaf petiole. Both the adults and nymphs have sucking mouthparts to pierce the leaf tissue and consume phloem sap. Adults prefer to congregate and alight on the immature upper leaves of the cassava plant (Sseruwagi et al., 2004). The first nymphal stage is mobile until it finds a suitable feeding location. The nymphs exude honeydew, which falls onto the lower leaves of the plant leading to sooty mould development.

There are a range of abiotic and biotic factors (e.g. host-plant availability, weather, mortality from natural enemies, etc.) that may influence the abundance of any pest herbivore on a host plant. Understanding how these factors relate to population dynamics and distributions measured at the field level and scale-up to the regional level is critical for determining if a pest outbreak is likely to occur. We define an outbreak situation as one in which the pest herbivore or plant-virus vector has been released from control, has reached high abundances, and is causing economic injury to the crop. This problem usually manifests at the field or regional scale. Importantly, crop damage can occur at low pest abundance, especially in the case of virus transmission. Thus, whilst outbreaks are often obvious to farmers and the general community, significant yield loss and damage can occur in non-outbreak situations. Here we focus on the documented evidence of factors that influence abundance of $B$. tabaci on cassava in East Africa. There are likely to be a number of factors that will, in isolation or in combination, influence the abundance of $B$. tabaci in cassava landscapes. We have classified these into biotic (cassava cultivar, cassava age, cassava virus infection status, non-cassava host plants, natural enemies, competition with other herbivores and endosymbionts), abiotic (altitude, climate and weather) and other factors (pesticides, hybridization) in table 1.

\section{History of B. tabaci abundance on cassava and outbreaks in East Africa}

There has been a change in the abundance of $B$. tabaci in cassava production landscapes in East Africa in general over time (fig. 1). However, quantitative definitions of what is a high or low population abundance have also changed across time; therefore, empirical evidence documenting this change is weak. The threshold of the number of adults considered highly abundant, however, differs between studies, and we cannot translate abundance data into likely yield loss. Early research from Ivory Coast considered cassava a poor host for B. tabaci, as numbers rarely exceeded 300 adults per plant and more often there were 150 adults per plant (Fishpool \& Burban, 1994; Fishpool et al., 1995; Colvin et al., 1998;). However, other researchers might consider these to be relatively high numbers. In Legg et al. (2011) when $>5$ adults per top five leaves per plant were recorded, this was considered highly abundant. In contrast, Omongo et al. (2012) only considered populations $>20$ adults per top five leaves per plant as high. Some quantitative studies have been summarized in table 3; however, it is still challenging to compare across studies that have used different sampling methodologies to document overall trends. Sseruwagi et al. (2004) provides a summary of mean number of $B$. tabaci from top five leaves from African studies prior to 2004 . 


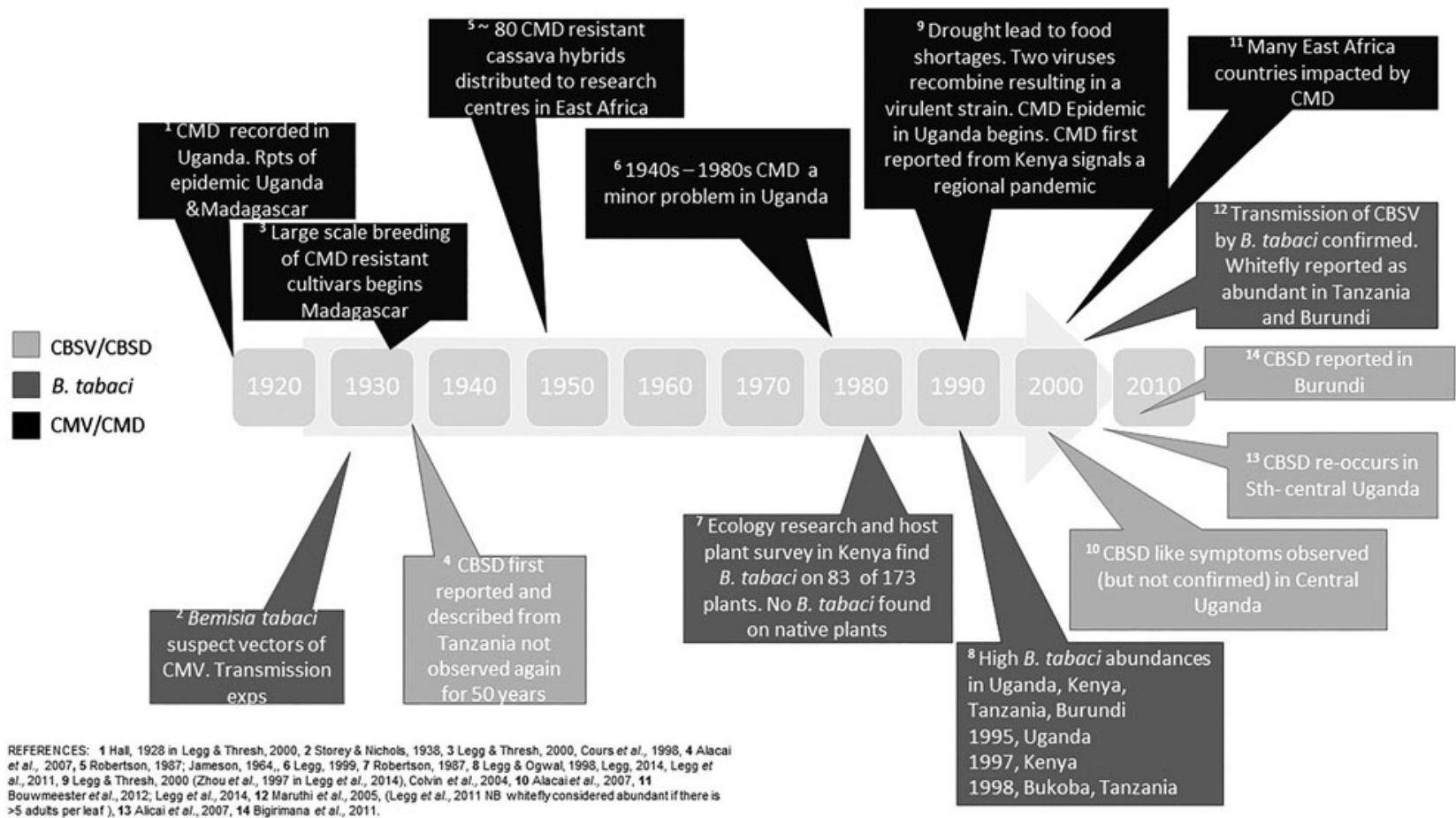

Fig. 1. Timeline of events of Bemisia tabaci and associated disease outbreaks in East Africa. CMV, cassava mosaic virus; CMD, cassava mosaic disease; CBSV, cassava brown streak virus, CBSD, cassava brown steak disease.

We have summarized the available evidence on the historical outbreaks of B. tabaci, and the two major diseases of cassava, CMD and CBSD, across East African countries in fig. 1. There are records of high populations of $B$. tabaci causing problems for farmers since the 1990s. As with most pest outbreaks, there is a focus on data collection and analysis during the outbreak phase, until an intervention (e.g. the introduction of new cassava cultivars) or change in the environment stops the outbreak, but a lack of information in the intervening periods. This makes it challenging to assess the causes and frequency of outbreaks, both at the local level and across the East African region. It is notable that the movement of infected cuttings (between regions within countries, and between countries) was implicated in a number of historical outbreaks (Alicai et al., 2007). Importantly, the introduction and dissemination of new CMD-resistant cultivars to combat food shortages because of epidemics was also facilitated through these routes. Less well documented is that disease sources can be present in endemic host plants such as Jatropha sp., and trade routes between India and Africa may have also facilitated disease spread (Swanson \& Harrison, 1994).

\section{Plant virus transmission by $B$. tabaci}

Outbreaks of CMD, which are at least partially whiteflyborne, have been occurring in East Africa since the 1960s (Jameson, 1964). A detailed description of both CMD and CBSD can be found in Mabasa (2007), but we will summarize some of the key points here. There are seven cassava mosaic begomoviruses (CMBs) (Geminiviridae; genus Begomovirus) that are related to CMD (Legg et al., 2015). The first widespread outbreaks of CMD were reported in the 1930s in East Africa (Storey \& Nichols, 1938; fig. 1) and the presence of CMD is now confirmed in cassava across East Africa. CMBs appear to be persistent in $B$. tabaci; however, there may be some co-adaptation between the viruses and different vector species that alter their ability to transmit virus to cassava (see Maruthi et al., 2002b). Severe infection causes stunting of shoots, leaves and stems which reduce tuber growth and subsequently yield (Fauquet \& Fargette, 1990; Maruthi et al., 2002a, b; Omongo, 2003). There is a latent period after the first leaves appear of about 1 month between time of infection by $B$. tabaci and CMD symptom expression in cassava (Fauquet \& Fargette, 1990). Symptoms increase until approximately 60 days after planting. However, infection introduced beyond 5 months after planting (MAP) via $B$. tabaci has very little impact on the yield. This is because at five MAP, the tubers have started to form and the plant is still able to provide significant yield (Fargette et al., 1990).

The second major cassava plant disease associated with $B$. tabaci is CBSD. CBSD is often found together with CMD, but this was not always the case (Alicai et al., 2007). Historically, CBSD was thought to be caused by two distinct viruses, cassava brown streak virus (CBSV) and Ugandan cassava brown streak virus (UCBSV), but Ndunguru et al. (2015) have recently found more genetic diversity in both CBSV and UCBSV, suggesting that there may be more than two viruses involved. Both virus groups belong to the genus Ipomovirus, and family Potyviridae (Mbewe et al., 2015); however, CBSV has a five times faster rate of evolution, and is more virulent compared with UCBSV (Alicai et al., 2016). Unlike CMBs, CBSVs are semi-persistent in B. tabaci (Maruthi et al., 2005). Symptoms of CBSD include yellow blotchy patches on the leaves and a change in the 
Table 3. Studies quantifying the mean number of adults (unless otherwise mentioned) Bemisia tabaci on cassava. General method used was counting the numbers of adults observed on the top five expanded leaves on 30 plants per field and on cassava aged 3-6 months after planting (Sseruwagi et al., 2004). There was some variation in methods between studies.

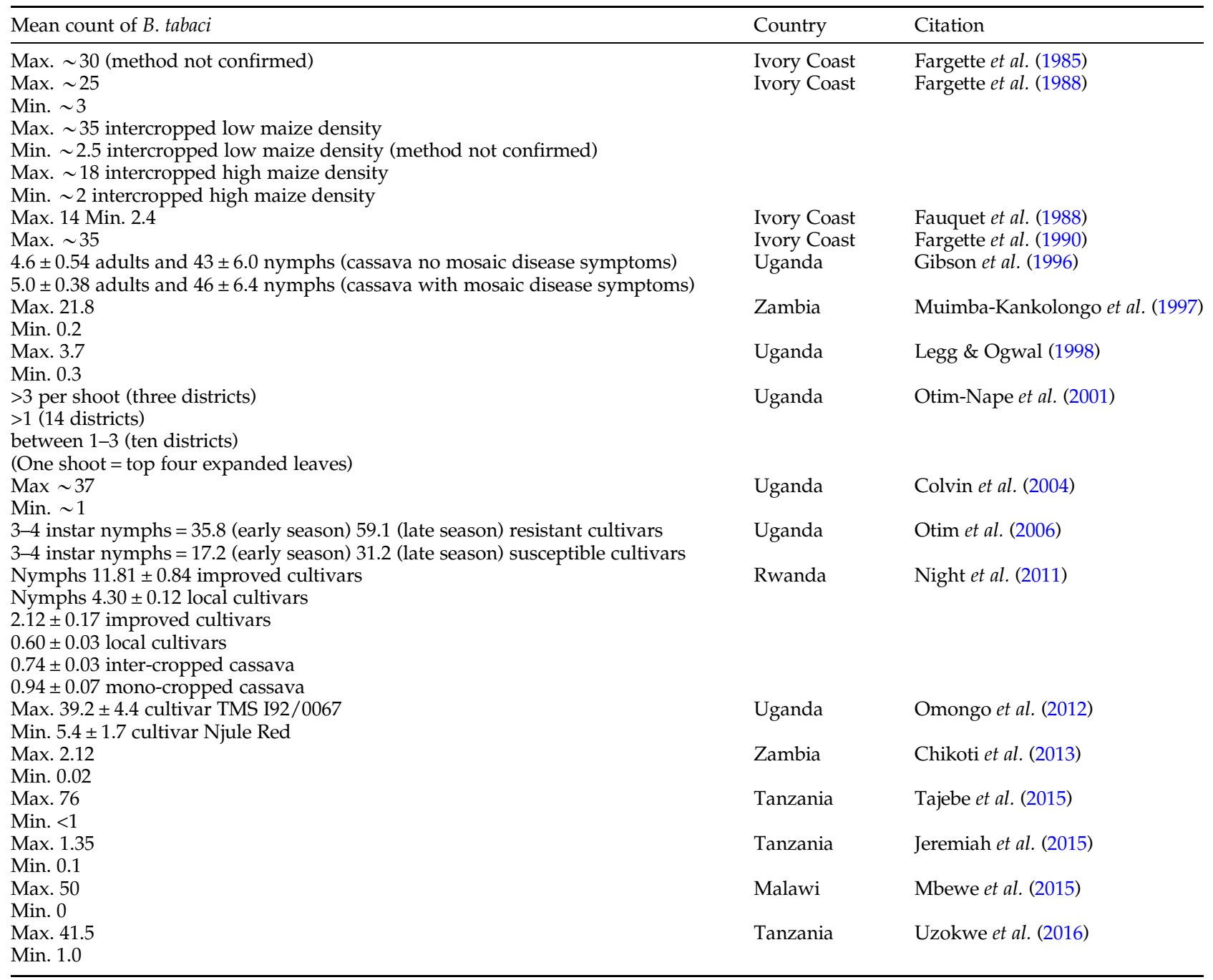

colour of the leaf veins, especially on the lower more mature leaves. Brown coloured vertical lesions occur on the stems and roots can become contorted and constricted. Cross-sections of roots from infected cassava plants show brown necrotic tissue (Nichols, 1950; Hillocks \& Jennings, 2003; Ntawuruhunga \& Legg, 2007).

Bemisia tabaci species can carry and potentially transmit hundreds of different plant viruses (Morales \& Jones, 2004; Polston et al., 2014). Harrison et al. (1997) makes the argument that selection and subsequent spread of viruses by certain $B$. tabaci species might be possible. Different species of $B$. tabaci are believed to be able to transmit Geminiviruses with different coat proteins (McGrath \& Harrison, 1995; Maruthi et al., 2002a; Morales \& Jones, 2004, b). This may be important; however, methods to test for these synergistic virus-vector relationships are rare (Patil \& Fauquet, 2010). Both CMD and CBSD are spread through the propagation of infected cassava cuttings and vectored by B. tabaci in East Africa (Maruthi et al., 2005; Jeremiah et al., 2014, confirmed B. tabaci transmits
CBSVs). Transmission of CMBs by $B$. tabaci has been confirmed in Africa (Burban et al., 1992; Fishpool \& Burban, 1994; Gibson et al., 1996; Legg et al., 2002; Antony et al., 2006). Survey of cassava across Tanzania during the 19931994 growing season showed that on average $27 \%$ of plants had CMD symptoms, of which $3 \%$ could be attributed to $B$. $t a-$ baci transmission, compared with $24 \%$ of infections to the use of infected cuttings (Legg \& Raya, 1998). More recently, it has been shown that a greater proportion of CMD is cutting borne compared with being vectored by B. tabaci (Night et al., 2011). A modelling study exploring CBSD spread showed that in a scenario with whitefly dispersal alone, large-scale epidemics were less likely than when trade of infected cuttings is also included in the model (McQuaid et al., 2017). Research by Dubern (1994) indicated that B. tabaci was not an efficient vector of CMBs. However, Maruthi et al. (2002a, b) used $\mathrm{CMB}$ isolates and B. tabaci sourced from four different areas (three African locations and one culture from India) to show that African CMBs were transmitted by African B. tabaci to 
$60-79 \%$ of the cassava plants. However, inoculation was significantly less when Indian B. tabaci transmitted an African CMD isolate and vice versa when B. tabaci from Tanzania transmitted CMB isolates from India. These results were used to support the idea that there is virus and or vector co-adaptation and that there is variability in vector competence and biological traits between B. tabaci species (Maruthi et al., 2002b). However, there is little quantifiable evidence for this hypothesis, and what evidence there is has been drawn from data that have a small number of samples (Xu et al., 2010).

\section{Factors influencing $B$. tabaci abundance}

Below we summarized the available evidence that may demonstrate a link with each factor and change in abundance of $B$. tabaci populations.

\section{Biotic factors \\ Cassava cultivar effects}

The primary way to manage disease in cassava has been to develop cultivars that are disease resistant or tolerant (these are often referred to as 'improved cultivars'). Observations that some cultivars were susceptible to disease have been evident since the first outbreak of CMD in the 1930s (Storey \& Nichols, 1938). The key response to the 1990s CMD epidemic was to distribute cassava cuttings from improved cultivars (Oliveira et al., 2001). In recent times, greater numbers of adult $B$. tabaci, and sometimes nymphs, have been associated with recently developed cultivars, although the dynamics of $B$. tabaci populations in semi-field situations have not been well documented (e.g. Katono et al., 2015). Severity of cassava green mite (CGM; Mononychellus tanajoa) and CMD were higher on local cultivars of cassava, although $B$. tabaci populations were higher on improved cultivars (Night et al., 2011). To determine which cultivars showed some level of phenotypic resistance or tolerance to $B$. tabaci, 19 cultivars were exposed to $B$. tabaci for colonization. Numbers of nymphs, eggs, damage and sooty mould were greatest for cultivar 192/0067 and least for Njule Red (a local cultivar) (Omongo et al., 2012). Cassava leaf area did affect the severity of sooty mould (i.e. a cultivar with a lower number of $B$. tabaci could have a higher sooty mould severity score, presumably due to broader leaves). However, there was no obvious correlation between the numbers of $B$. tabaci adults and cultivar plant traits such as leaf width or colour (Omongo et al., 2012).

Beyond the obvious differences in plant morphology seen between different cassava cultivars, plant biochemistry may also play a role in determining suitability for growth and development of $B$. tabaci populations. Research on the phytochemistry of cassava has largely concentrated on defensive metabolites such as flavonoids, hydroxycoumarins, terpenoids and cyanogenic glucosides and their distribution within plant tissue. This work was recently reviewed by Blagbrough et al. (2010). Cassava phytochemistry can impact phloem feeders, with examples including the effect of its flavonoids and cyanogenic glucosides on the cassava mealybug, Phenacoccus manihoti (Calatayud et al., 1994a, b, 1997) and the cassava hemipteran pest, Cyrtomenus bergi (Riis et al., 2003). Bemisia tabaci can also be affected, and has been shown to induce cyanidemetabolizing enzymes when feeding on cassava compared with sweet potato (Antony et al., 2006). These results provide evidence that defensive plant metabolites play an important role in cassava colonization by phloem feeders including $B$. $t a-$ baci. However, how the phytochemistry of different cassava cultivars and tissues influences $B$. tabaci resistance remains unknown. Future efforts should be directed at confirming these mechanisms and explaining the effect of cassava plant chemistry on phloem feeders and other herbivores within the East African cassava environment.

\section{Cassava age}

As cassava matures, the degree to which it is a suitable host plant for B. tabaci changes. There are likely to be several factors associated with the ageing process such as changes to leaf morphology, plant biochemistry and B. tabaci preference and learning that impact this process. The population of $B$. tabaci builds up starting at three MAP and peaks between five and seven MAP (Sseruwagi et al., 2003), when the foliage is very well formed and succulent after which it drops drastically as the plants grow taller, become more woody (less succulent) and shade the leaves. However, overall, the dynamics of $B$. $t a-$ baci populations in the field in response to factors that change as cassava ages have not been well documented.

All the cultivars surveyed in Uganda in 1990-1992 were susceptible to CMD (Otim-Nape et al., 1998), but as cassava plants age, the rate at which the CMD spreads is reduced (Fargette et al., 1993). Cuttings taken from the top of the plant are more likely to be virus-free for CBSD compared with those taken from the bottom of the plant (Mohammed et al., 2016), which may be related to plant age. During sampling for virus detection, virus titre is always highest in the older leaves for CBSVs, especially in the young $(<6$ months old) cassava plants. Research to identify the resistance mechanisms in cassava cultivars shows that some cultivars can recover as the plants age (known as reversion, Adriko et al., 2011). CMD symptoms disappeared and cuttings taken from initially infected plants developed without disease symptoms (Gibson \& Otim-Nape, 1997; Adriko et al., 2011).

\section{Cassava virus infection status}

There are some empirical studies that have tested the hypothesis that there is a relationship between disease severity in a plant and B. tabaci abundance (Gregory, 1948; Leuschner, 1977; Robertson, 1987; Fargette et al., 1993; Otim-Nape et al., 1995; Colvin et al., 2004). If this is due to correlation or causation it is often hard to untangle. The abundance of $B$. tabaci adults was shown to be significantly higher on healthy cassava plants compared with infected plants, but adults stayed longer on diseased plants and aggregated on the green plant tissue. This resulted in higher density of adults by photosynthetic leaf area (area of living leaf tissue) compared with plants without disease. Omongo (2003) posits that this increased density might trigger the adults to disperse. Results also show that adults are more likely to move from clean to infected plants, and diseased plants increased fecundity (Omongo, 2003).

Cassava plants infected with $\mathrm{CMBs}$ have been reported to be more suitable for growth and development of B. tabaci. A summary of the studies showing the effect of virus infection of host plants on $B$. tabaci population growth, development and behaviour can be found in Colvin et al. (2006). Concentrations of amino acids have been shown to be greater in infected cassava, and these may benefit B. tabaci fitness (Colvin et al., 1999, 2006). However, other laboratory studies have found that the status of cassava disease and B. tabaci (i.e. viruliferous or non- 
viruliferous) had no significant effect on life-history factors, sex ratio and developmental period, or per cent adult emergence (Thompson, 2011). Additionally, the longevity of B. tabaci was shown to be reduced when they carry viruses such as tomato yellow leaf curl virus (Berlinger et al., 1996). Therefore, whilst infection status plays some role in altering the bottom-up resources for B. tabaci, we cannot say when and how this will lead to high abundance in a field situation.

\section{Non-cassava host plants}

Bemisia tabaci is a polyphagous herbivore that can potentially use a wide range of different host plants in cassava production landscapes. Evidence from outside of Africa (Bellotti et al., 2005) and from West Africa (Burban et al., 1992) shows that $B$. tabaci can have very different associations with different host plants in different locations indicating the likelihood of host-plant associated genotypes. Research in West Africa showed two genotypes of B. tabaci; one polyphagous on a range of plants (excluding cassava) and the second found only on Euphorbia species (this group includes cassava) (Burban et al., 1992). Laarif et al. (2015) found that B. tabaci Mediterranean (MED, formally named biotype Q) preferred host plants in the families Verbenaceae and Malvaceae, and Middle East-Asia Minor 1 (MEAM1, formally named biotype B) were found on Cucurbitaceae and Solanaceae. SSA2 only occurred on Datura and eggplant (Laarif et al., 2015). Their results support the argument that the genetic differentiation of $B$. tabaci species does not operate at the plant species level, but more likely in response to broader taxonomic grouping, for example, plant families. Table 4 documents host plants that have been recorded in recent publications that included a genetic determination of the species. Most of the studies rely on adults (which are highly mobile) recorded on host plants, except Sseruwagi et al. (2006) who used nymphs to confirm the results obtained with adults for host-plant colonization. There is a supposition that the number of eggs laid on a plant is a better indicator of a preferred host compared with counts of adults (Laarif et al., 2015). Further information is required that shows clear specieshost-plant relationships in field contexts, such as preference tests, rate of nymphal development and mortality on host plants (not just presence or absence).

Experiments transferring B. tabaci from natal host plants to different local host plants result in failure or variable establishment. These results were used to support the idea that there are different $B$. tabaci genotypes with restricted host ranges (Burban et al., 1992). However, this research did not test the influence of host-plant transfer on ability of B. tabaci to transmit disease. Research by Antony et al. (2006) showed that natal host plants influence the ability of $B$. tabaci to transmit Indian cassava mosaic virus (ICMV). Whereas $B$. tabaci reared from cassava could transmit ICMV to cassava, B. tabaci reared on sweet potato were unable to transmit ICMV to cassava. There was a significant difference in the presence of the cyanide detoxifying enzymes in cassava reared B. tabaci compared with those reared on sweet potato. Together, the results show the ability of $B$. tabaci to adapt to different host plants.

Intercropping cassava with other crop plants (e.g. coffee, maize, sweet potato, bean, groundnut) is common practice in many parts of East Africa. However, beyond saying if a crop is likely to be a host plant or not, we cannot yet make recommendations about which intercrop would be most useful for reducing $B$. tabaci abundance on cassava. Intercropping cassava with maize was shown to reduce $B$. tabaci population abundances in the Ivory Coast (Fargette et al., 1988), although the mechanism here may not be related to host-plant preferences, but rather host-plant availability and physical barriers (i.e. maize are not host plants and may create a barrier to accessing host plants). Intercropping cassava with cowpea has been shown to decrease numbers of $B$. tabaci in Colombia (Gold et al., 1989). Results of surveys in Uganda in 2007 showed that intercropped cassava had significantly less $B$. tabaci than monocrops (Night et al., 2011). Experiments intercropping cassava with Vigna unguiculata and Vigna radiata (cowpea and green gram mung bean) showed reduced $B$. tabaci populations and severity of CMD. Disease-free cuttings of two cultivars (one susceptible local cultivar and one improved cultivar) were used in field experiments. Compared with monocrop treatments, the cultivars intercropped with mung bean had significantly less B. tabaci and disease incidence and severity for both the local and improved cultivar (Uzokwe et al., 2016).

\section{Spatial and temporal arrangement of host plants}

As well as the influence of intercropping per se on B. tabaci populations in cassava fields, the spatial and temporal arrangement of crops and other potential non-crop hosts around cassava fields may also influence population growth and abundance in the crop field, especially early in the growing season. In theory, if host plants surrounding cassava fields facilitated the early arrival (and high numbers of colonizers) of the first generation of $B$. tabaci into the cassava field in the early stages of the crop, this may lead to an outbreak. Furthermore, if the spatial and temporal arrangement of host plants negatively impacted the dynamics of natural enemies of $B$. tabaci, this could also lead to an outbreak.

In a farming landscape where a species of $B$. tabaci (MEAM1) has been shown to be polyphagous with several crops and wild host plants suitable to support population growth (Queensland, Australia, Sequeira et al., 2009; De Barro, 2012), it was possible to develop a landscape model to simulate how the spatial and temporal arrangement of host plants influences $B$. tabaci abundance and 'outbreaks'. The model simulations indicated that peak densities of MEAM1 B. tabaci were higher for low or non-suitable crops than for crops with a medium suitability. This counter-intuitive result was explained by the fact that medium suitability winter crops supported high parasitoid (Eretmocerus hayati) populations, which can suppress $B$. tabaci populations in summer crops (De Barro, 2012; Kristensen et al., 2013). Therefore, both the surrounding landscape and crop rotation choices had a significant effect on simulated B. tabaci population dynamics.

Understanding how the farming landscapes in East Africa offer resources for both $B$. tabaci and its natural enemies is challenging due to the variegated nature of the land-use patterns characteristic of smallholder farming. Often there are multiple crops planted in each field or garden and rotation practices are flexible and dependent on the family, village and regional demand for certain food types. However, studies to quantify the effect (even if small) of the spatial and temporal arrangement of host plants are needed because this knowledge may lead to easily adoptable changes in management practices.

\section{Natural enemies}

Breeding cassava cultivars that are resistant to disease has been the main approach used to manage epidemics of CMD. 
Table 4. Host plants of Bemisia tabaci in East Africa from the published literature.

\begin{tabular}{|c|c|c|c|}
\hline Host plant & Common name & B. tabaci genotype & References \\
\hline Ocimum gratissimum & Wild basil & Ug3 & Sseruwagi et al. (2005) \\
\hline Cucurbita pepo & Squash & Ug4, MED, EA1 & Sseruwagi et al. (2005); Tajebe et al. (2015) \\
\hline Leonotis nepetifolia & $\begin{array}{l}\text { Klip dagga, Christmas candlestick } \\
\text { or lion's ear }\end{array}$ & $\begin{array}{l}\text { Ug4 } \\
\text { EA1, MED, IO }\end{array}$ & Sseruwagi et al. (2005); Tajebe et al. (2015) \\
\hline Pavonia urens & Malvaceae, hibiscus-like flower & Ug4 & Sseruwagi et al. (2005) \\
\hline Phaseolus vulgaris & Bean & Ug7 & Sseruwagi et al. (2005) \\
\hline Abelmoschus esculentus & Okra & Ug1, Ug6, EA1 & Sseruwagi et al. (2005); Tajebe et al. (2015) \\
\hline Lycopersicon esculentum & Tomato & Ug1, Ug8, SSA1, IO & $\begin{array}{l}\text { Sseruwagi et al. (2005); Tajebe et al. (2015); } \\
\text { Delatte et al. (2011) }\end{array}$ \\
\hline Gossypium hirsutum & Cotton & Ug8, EA1 & Sseruwagi et al. (2005); Tajebe et al. (2015) \\
\hline Ipomoea batatas & Sweet potato & Ug1, EA1, MED, SSA1 & Tajebe et al. (2015) \\
\hline Lantana spp. & Lantana and hibiscus & MED, in Tunisia & Laarif et al. (2015) \\
\hline
\end{tabular}

*The names used here are the same as authors used in their papers, however see section on species identification.

However, as part of an integrated management plan to control $B$. tabaci, identifying ways to enhance naturally occurring predators and parasitic wasps also needs to be considered (Legg et al., 2003). Fishpool \& Burban (1994) noted that there were 30 parasitoids of $B$. tabaci worldwide, and 40 generalist predators. However, the ecology and impact of parasitoids and predators of $B$. tabaci in East Africa remains relatively unknown.

Regarding predators, Phytoseiidae mites, such as Euseius scutalis, have been recorded predating $B$. tabaci populations on cassava in Kenya (Otim-Nape et al., 1995), and mirids, such as Nesidiocoris tenuis, have predated B. tabaci on other crops such as tomato (Calvo et al., 2012). Results from petri dish experiments with $B$. tabaci from cotton showed that the predatory mite Amblyseius aleyrodis Elbadry readily consumed B. tabaci eggs in a no-choice environment (Elbadry, 1968). Similarly, from the work carried out in the USA, Euseius hibisci were shown to consume and complete their development on B. tabaci (Meyerdirk \& Coudriet, 1985). Other predators of $B$. tabaci nymphs from around the world include Stethorus jejunus Casey, Coccinellidae, Holoborus pallidicornis (Cameron) Staphylinidae and Scolothrips latipennis Priesner, Thysanoptera (Fishpool \& Burban, 1994). The Neuropteran Conwentzia africana Meinander is considered an important predator of B. tabaci (Legg et al., 2003). Serangium sp. (Coleoptera: Coccinellidae) can complete their development feeding on juvenile stages of $B$. tabaci on cassava (Asiimwe et al., 2007a, b). No-choice laboratory experiments showed that Serangium larvae could consume over 1000 nymphs in total. The maximum number of nymphs consumed per day was mid-way through their development, when Serangium larvae consumed over 200 nymphs per day (Asiimwe et al., $2007 a, b)$. We know that cultivars of cassava with different morphologies can influence the activities of predators such as Typhlodromalus aripo, the mite that preys on the pest CGM M. tanajoa (Zundel et al., 2009).

Legg \& Hillocks (2003) lists the parasitoids attacking Bemisia genus in SSA. Thirty-four species of Encarsia and 14 species of Eretmocerus, with Eretmocerus mundus Mercet and Encarsia sophia Girault and Dodd being the most dominant (Legg et al., 2003). Surveys of B. tabaci parasitoids in cassava in Tanzania identified using a molecular approach, ten species of parasitoids (Guastella et al., 2015). Hoelmer et al. (1995) summarized several papers that suggested that parasitoids may be insufficient to control $B$. tabaci without other control methods. However, parasitism rates of up to $58 \%$ have been recorded in Uganda (table 5). Some work has been completed to quantify the impact of parasitoids on B. tabaci.

Eretmocerus mundus and E. sophia were shown to parasitize B. tabaci on cassava in Uganda and accounted for $34 \%$ parasitism of fourth instar nymphs (Legg, 1995). Significantly higher number of $B$. tabaci and parasitoids occurred on the CMD-resistant cultivar compared with a susceptible cultivar although parasitism rate was similar. Although not tested for specifically, the cultivar and presence or absence of CMD did not seem to influence parasitism rates. Per cent parasitism was recorded as $<20 \%$, and on three occasions $<50 \%$. However, results showed a significant negative relationship between parasitism rate and nymph numbers indicating that these parasitoids did not respond in a density-dependent manner (Otim et al., 2006). Life-history studies conducted under field conditions showed that dislodgement was the key mortality factor for eggs and that parasitism (mostly by E. sophia and E. mundus) caused the highest mortality to fourth instar nymphs. There was no difference in results from the treatments exposed to, or sheltered from, the rain (Asiimwe et al., 2007a, b).

There has been little research to understand how different cassava cultivars might influence the activities of natural enemies of B. tabaci. We know that cultivars of cassava with different morphologies can influence predators such as $T$. aripo (the mite that preys on M. tanajoa, Zundel et al., 2009), and there have been some basic experiments conducted using parasitoids (Otim et al., 2008). However, a comprehensive understanding of cultivar impacts at higher trophic levels is critically needed. 
Table 5. Records of parasitism of Bemisia tabaci from field studies in East Africa.

\begin{tabular}{|c|c|c|c|c|}
\hline Citation & Location/study type & Host plant & Parasitoid species recorded & Percentage parasitism \\
\hline Otim et al. (2005) & Namulonge, Uganda. Survey data & Cassava with B. tabaci & $\begin{array}{l}\text { Eretmocerus mundus } \\
\text { Encarsia mineoi } \\
\text { Encarsia sophia } \\
\text { Encarsia 'blackhead' } \\
\quad \text { (undescribed) }\end{array}$ & $40-58 \%$ \\
\hline Otim et al. (2006) & $\begin{array}{l}\text { Namulonge, Uganda. Field study on } \\
\text { cassava cultivars }\end{array}$ & Cassava with $B$. tabaci & $\begin{array}{l}\text { E. mundus } \\
\text { E. sophia }\end{array}$ & $20-58 \%$ \\
\hline $\begin{array}{l}\text { Guastella et al. } \\
\text { (2015) }\end{array}$ & $\begin{array}{l}\text { Mwanza, Shinyanga and Tabora, } \\
\text { Tanzania. Survey data }\end{array}$ & Cassava & $\begin{array}{l}\text { E. sophia } \\
\text { En. guadeloupae } \\
\text { En. dispersa } \\
\text { En. lutea } \\
\text { En. mineoi } \\
\text { En. sp. pr. circumsculpturata } \\
\text { Er. mundus } \\
\text { Er. sp.pr. hayati or } \\
\text { queenslandensis } \\
\text { Er. sp. } 1 \\
\text { Er.sp. } 2\end{array}$ & $\begin{array}{l}\text { Parasitism levels not } \\
\text { determined }\end{array}$ \\
\hline
\end{tabular}

\section{Competition with other herbivores on cassava}

Competition between $B$. tabaci and other herbivores on cassava may impact the abundance of $B$. tabaci. For example, the CGM M. tanajoa is often found on the top leaves of the cassava plant, making these leaves less suitable for B. tabaci adults (Legg et al., 2015). Interspecific interactions between pests on the same crop can significantly influence invertebrate behaviour and host-plant defences; for example, the duration and density of the aphid Myzus persicae on tomato significantly affected the number of B. tabaci (Tan et al., 2014). We could find no studies that examine the interactions between the community of pest and non-pest herbivores on cassava in East Africa.

\section{Endosymbionts}

Some evidence exists that endosymbiotic bacteria within $B$. tabaci can have both positive and negative effects on $B$. tabaci fitness (Kontsedalov et al., 2008; Himler et al., 2011; Ghosh et al., 2015). Portiera aleyrodidarum is a primary obligate bacterial endosymbiont of $B$. tabaci, and is essential to their development. As well as obligate bacteria, they have an association with many facultative bacteria or secondary endosymbionts. In theory, these bacteria may confer some advantage for transmission of CMBs by B. tabaci and help them adapt to new host plants (Gottlieb et al., 2010; Kliot et al., 2014).

The association between facultative secondary endosymbionts and various species of $B$. tabaci was explored using samples collected in Tanzania from cassava and adjacent host plants, mostly crops and one weed (Tajebe et al., 2015, see graphic depicting relationships between different groups of $B$. tabaci such as SSA1-SG1). Most B. tabaci collected from cassava were SSA1 and most were uninfected by any of the secondary symbionts. A later study found contrasting results (Ghosh et al., 2015). Samples of B. tabaci were collected from cassava crops across East African countries were found to be infected with a range of endosymbionts, with the predominant species being Wolbachia, Rickettsia and Arsenophonus. The prevalence of these secondary endosymbionts including
Wolbachia varied characteristically across each B. tabaci population (Ghosh et al., 2015). Association of the endosymbionts varied across geographical boundaries and the B. tabaci species. SSA1-SG3 in coastal Eastern Africa had high levels of Arsenophonus and Rickettsia in single or mixed infections $(84 \%)$, while a small proportion (13\%) was free of detectable secondary endosymbionts (Ghosh et al., 2015). In contrast, SSA1-SG1 collected in the highland regions of Uganda and around Lake Victoria had different secondary endosymbiont profiles. About 25\% of SSA1-SG1 individuals were infected with Arsenophonus and Rickettsia in single or mixed infections, while equal proportion of endosymbiont-free (38\%) and Wolbachia-infected individuals $(37 \%)$ were found in Uganda. In laboratory studies, all three bacteria (Wolbachia, Arsenophonus and Rickettsia) were shown to negatively impact $B$. tabaci population development by reducing adult emergence and simultaneously increasing nymph development time, thereby reducing number of adults and the number of generations that can be developed per unit time (Ghosh et al., 2015). In addition to several factors discussed above, it has been proposed that high levels of bacteria-free B. tabaci, which are fitter and more fecund, may have contributed to high abundances in certain regions. Similar effects have been observed in Drosophila and mosquitoes infected with Wolbachia (McMeniman \& O'Neill, 2010). Thus, it is possible that the negative effects of endosymbionts in $B$. tabaci have been important population control mechanisms in these regions.

\section{Abiotic factors}

\section{Altitude}

There is evidence in the literature that altitude relates to population abundance of $B$. tabaci. However, the mechanism underlying any altitudinal variations seen in the few studies available (e.g. temperature, rainfall gradients, change in farming systems and crops grown) have not been tested (or in some cases even described). There is some evidence to suggest that cassava virus infection was lower in areas above $800 \mathrm{~m}$ above 
sea level (Legg (1994)). Legg \& Raya (1998) found a significant negative correlation between CMD incidence and altitude in Tanzania. Historically, it has been noted that at high altitudes (>1000 $\mathrm{m}$ above sea level), there are less plant disease problems and an absence of $B$. tabaci in cassava, presumably due to cold temperatures. In general, there is evidence of a trend of declining CBSD incidence with increasing altitude in the coastal zone of Tanzania, but not in the lake zone (Jeremiah et al., 2015).

\section{Climate and weather}

As with all invertebrate pest species, long-term climate patterns and short-term weather events will influence population growth and development of $B$. tabaci. However, drawing conclusions beyond general statements is challenging due to a lack of information for the species associated with cassava in East Africa. In general, B. tabaci populations are favoured by high temperatures and moderate rainfall (Sseruwagi et al., 2004). Robertson (1987) described increases in the abundance of $B$. tabaci along coastal Kenya related to an increase in annual rainfall, and increased activity of flying adults after the end of rainy periods. Recent analyses of $B$. tabaci adult abundance and environmental factors have shown that abundance was higher with high minimum temperatures and lower mean annual rainfall in the coastal zone of Tanzania (Jeremiah et al., 2015). However, in the lake zone of Tanzania, mean annual rainfall and the length of the growing season were the most important environmental factors. Some studies note generally when numbers of $B$. tabaci are likely to be low in cassava fields based on the time of the year when temperatures are low and the environment is unsuitable for B. tabaci (Mbewe et al., 2015). At a finer scale, we know that micro-climate variability within a field can influence the numbers of $B$. tabaci found on cassava plants. Bemisia tabaci adults decrease as planting density decreased and canopy temperatures increased (Otim-Nape \& Ingroot, 1986).

If we examine studies that include $B$. tabaci species more broadly (i.e. not just East African studies), humidity extremes (low humidity $<20 \%$ and high humidity $>80 \%$ ) can increase mortality of immature stages, and development rate of multiple life stages decreases dramatically with temperatures above $30-33^{\circ} \mathrm{C}$ (Gerling et al., 1986). Drost et al. (1998) used an upper lethal temperature of $36^{\circ} \mathrm{C}$ to fit a development rate model for immature $B$. tabaci on cotton. Laboratory studies have shown that $B$. tabaci survival ranges from $\sim 90 \%$ survival at $25^{\circ} \mathrm{C}$ and $100 \% \mathrm{RH}$, to $<2 \%$ survival at $41^{\circ} \mathrm{C}$ and $20 \% \mathrm{RH}$ (during a $2 \mathrm{~h}$ exposure) (Berlinger et al., 1996).

\section{Other factors and hypotheses}

\section{Pesticides}

The overuse of pesticides and rapid development of resistance in $B$. tabaci has been shown to cause high abundance and change the identity of the common $B$. tabaci species in other cropping systems around the world (e.g. Crowder et al., 2008). For example, a shift from $B$. tabaci MEAM1 species to MED species was found in cotton fields in Israel and this change in species composition had an impact on resistance to insecticides, with one population showing less resistance to insect growth regulators (Horowitz \& Ishaaya, 2014). However, the use of pesticides by East African smallholder farmers has historically been low due to their cost and availability, although their use is increasing each year (de Bon et al., 2014). Insecticide application in cassava production landscapes in East Africa is limited to crops such as tomatoes and other fruit and vegetables (de Bon et al., 2014). Documented statistics on pesticides use (and especially insecticide use) patterns in cassava by smallholder farmers in East Africa is rare. Surveys of honeybee hives throughout Kenya showed low levels of pesticide contamination in the hives (Muli et al., 2014). Documentation of the change in insecticide use patterns over time (products, active ingredients, crops, application rates and baseline levels of resistance) may help predict the onset of resistance development and help in the development of an integrated resistance management strategy.

\section{A new invasive species in East Africa}

Given the confusion surrounding the taxonomy of species in the $B$. tabaci complex, we cannot rule out that there have been one or multiple incursions of an entirely new species into this region over the recent historical period. As an analogous example from outside of East Africa, the exotic pest B. $t a-$ baci MEAM1 was first detected in Australia on ornamental plants in 1994, but it was not until 2001 that high numbers on fruit and vegetable required control (Gunning et al., 1995; Sequeira et al., 2009). After this new species entered East Africa, it may have been better able to exploit resources in cassava production landscapes, avoid attack by natural enemies, and outcompete domestic $B$. tabaci species. In addition to natural spread within the African continent, movement of species into new areas is possible via human-assisted transport (Caciagli, 2007). Yet there is no empirical evidence to support this idea in East Africa (table 1).

\section{Hybridization}

The B. tabaci abundance associated with the spread of the severe CMD pandemic in Uganda in the late 1990s was believed to be due to the appearance of an invasive SSA2 B. tabaci species (Legg et al., 2002;). However, subsequent studies by Sseruwagi (2005) and Mugerwa et al. (2012) showed SSA2 to be less abundant in Uganda post-invasion. Instead, the areas with high $B$. tabaci populations had a distinct clade of SSA1 (SSA1-SG1), and what was believed to be a hybrid of SSA2 and SSA1. More recently, Tajebe et al. (2015) also suggested hybridization as the underlying cause in the change from $B$. tabaci SSA2 to B. tabaci SSA1-SG1 in Tanzania, and that the CMD pandemic was now associated with high abundances of $B$. $t a-$ baci SSA1-SG1 genotype. However, empirical studies to confirm this hypothesis in East Africa have not yet occurred.

Empirically detecting such changes in field studies on a pest complex can be very challenging (but not impossible, see discussion in Liu et al., 2012). The process of hybridization is unlikely to be reflected by the mtDNA COI gene currently used for identification purposes. Given the mitochondrial DNA genome's overall maternal inheritance property and its general lack of recombination hybridization between a population carrying the SSA2 mtDNA COI haplotypes with the SSA1 mtDNA COI haplotypes would result in the hybrid offspring being either SSA2 or SSA1 mtDNA COI haplotypes, but is unlikely to generate the SSA1-SG1 mtDNA COI haplotype signature. To show evidence of hybridization, we need to focus on changes in patterns in the nuclear genome, and then link these patterns with ecologically relevant fitness traits 
that may increase population growth and abundance on cassava.

\section{Knowledge gaps}

Given that many of the factors that potentially influence $B$. tabaci abundance listed in table 1 have had very little research surrounding them in East Africa, and may interact with each other in antagonistic or synergistic ways; therefore, identifying which are the critical knowledge gaps is challenging. Our focus here is on identifying knowledge gaps, which if filled, may lead to more sustainable and durable solutions to $B$. tabaci-associated crop damage in East Africa. Underpinning all the knowledge gaps highlighted below is the species identification issue. Without well-documented species nomenclature, set within a robust framework for identifying new species, the biological and ecological information generated may be lost rapidly. The high priority knowledge gaps are outlined below.

\section{Which East African B. tabaci species commonly use cassava as a reproductive host plant?}

Whilst $B$. tabaci adults are highly mobile and can be found on a number of plants, establishing which species commonly use cassava as a reproductive host plant (i.e. they can oviposit and complete nymphal development) is important. It is these species for which we need to devise targeted management interventions to control. To address this research question requires the identification of large numbers of field-collected nymphs using nuclear molecular markers, and reciprocal crossing experiments using cultures developed from nymphs reared through to adults. Laboratory studies looking at basic life-history parameters of the different species under different temperatures and humidities could then be conducted. This is also the first step in establishing if these target species also use alternate host plants besides cassava.

\section{To what extent do non-cassava host plants contribute to the population dynamics of $\mathrm{B}$. tabaci and the spread of cassava diseases?}

Whilst establishing the diversity of potential host plants that can be used by B. tabaci in production landscapes is important, we must take this one step further and establish if, when and how, these alternate host plants impact $B$. tabaci abundance and disease spread in cassava crops. For example, can alternate host plants for $B$. tabaci serve as reservoirs of viruses that may be transmitted to cassava (Alabi et al., 2008)? If an alternative host plant is identified, but is relatively rare in the landscape, will it impact the population dynamics in cassava? Conversely, if an alternate host plant is common in the landscape, will its removal impact population dynamics in cassava? There are straightforward management recommendations that can be developed from improved understanding about alternate host plants and the role they play in an agricultural landscape.

How does the proportional availability of infected vs. uninfected cassava plants in a landscape influence disease risk and spread?

It has been suggested that B. tabaci shows preferences for infected cassava plants, and infection can alter the performance of $B$. tabaci at the population level. However, we do not understand how this manifests in real cassava production landscapes, with a diversity of cassava cultivars, showing different levels of disease. Modelling the spread of CMD via infected cuttings assuming that B. tabaci prefer infected over uninfected plants, in combination with the proportion of infected plants available, indicated this could have major implications for disease spread. Incorporating information at a landscape scale about which species of $B$. tabaci are efficient vectors of each virus would also improve model predictions. Extending this to a detailed quantification of yield loss due to cassava diseases in the presence and absence of $B$. tabaci at the field and landscape level is also necessary to inform future management options.

How can we use choice of cassava cultivars in production landscapes to reduce population abundances of $\mathrm{B}$. tabaci?

Besides establishing the effect of different cassava cultivars on the fitness and performance of B. tabaci, we need to provide recommendations that lead to population reductions or lower risk of outbreaks at the landscape level. An understanding of the relationship between disease dynamics across a landscape, B. tabaci movement between cultivars, and cultivar diversity and abundance is needed. From this understanding, we may be able to provide location-specific recommendations about the selection of ideal cultivars, guidance on rouging and cassava-free periods. Historically, the adoption of new and improved cassava cultivars has been variable within countries, so more effort to understand the best mechanisms for ensuring that the new cultivars that are adopted also lead to B. tabaci population reductions would be valuable.

\section{What is the impact of natural enemies in East Africa on B. tabaci and can they reduce the risk of outbreaks?}

Whilst we know there are a diversity of natural enemies present in cassava fields that can cause mortality of B. tabaci, we cannot say what role these species play in reducing the frequency or likelihood of $B$. tabaci outbreaks (and if this will impact disease outbreaks). Given that cassava is a crop with a relatively long growth season (compared with many vegetables), and now receives relatively little pesticide applications, it is important that we explore further the potential impact of natural enemies. Furthermore, the integration of natural enemies with other management options (e.g. host-plant resistance and habitat management) is critical.

There is very little information about the natural enemies that prey on different stages of $B$. tabaci in field conditions and the impact they have on $B$. tabaci. Therefore, there is a need to better understand their biology and behaviour (life history of individual species), their relationships and interactions with other predators and parasitoids, and quantify the impact they have on $B$. tabaci populations. For some groups, we lack fundamental information on whether they frequently predate on B. tabaci. For other factors, such as the effect of alternative host plants (i.e. do any provide an alternative source of natural enemies to recolonize cassava crops and attack $B$. $t a-$ baci), dispersal ability, response to semiochemicals, and methods to increase fitness and population growth need to be determined. It is important to quantify the scale at which natural enemies may have an impact (i.e. within a few tens of metres or within $100 \mathrm{~m}$ of a source field), to enable us to make specific management recommendations to farmers. 
How can we sustainably manage the use of insecticides in East Africa to delay or avoid resistance in $\mathrm{B}$. tabaci?

If insecticide use increases in the coming years, such as in vegetable crops in or near cassava, or in cassava itself, there is the potential for B. tabaci species attacking cassava to be exposed to strong resistance selection pressures. Experiences in cotton production landscapes elsewhere have shown that resistance can develop quickly in B. tabaci (Crowder et al., 2008; Gnankine et al., 2013) and studies should consider establishing baseline levels of resistant alleles in populations now. Furthermore, the testing and development of products based on newer chemistries, which have less non-target impacts, needs to be conducted in East Africa.

What research methodologies do we need to develop now to enable scientists to ask the right questions in the future?

Throughout this review, we have highlighted methodological limitations that restrict research and the questions that scientists can address. For example, we need a smarter way of estimating $B$. tabaci adult numbers in fields with high abundances. In cases where nymphal or egg data may provide a more informative picture of a certain ecological process, counting adults could be avoided. We can develop new and fast approaches to count, collect, record and identify nymphs if that is what is needed to address a research question. A fieldbased method that allows us to separate virus infection borne by $B$. tabaci, from that borne by cuttings (or a combination of both agents) would greatly aid in our understanding of $B$. tabaci as a vector (see an example in Tajebe et al., 2015). A rapid diagnostic test for virus infection at the cutting stage would enable researchers to decide which factors they wanted to examine in their study, and be confident of their results. In addition, the advent of an infield diagnostic strip would allow scientists to detect virus at a given period and easily map patterns of disease spread. In another example, the recent development of a transcriptome technique that can provide data from one B. tabaci individual by Sseruwagi et al. (2017 submitted) will reduce reliance on the use of isolines for transcriptomics studies, and could therefore help to resolve some of the urgent questions about the biological differences between $B$. tabaci species.

What are the economic trade-offs associated with different management options for smallholder farmers, and what networks need to be available to support adoption?

Fundamental to the deployment of new management interventions, and adoption by farmers, is strong extension networks with smallholder farmers and the wider cassava value-chain actors. Without this network, the adoption of durable solutions to $B$. tabaci control will be slow or unlikely to occur. Furthermore, a complete economic assessment of the trade-offs for smallholder farmers associated with adopting different practices is needed to ensure that management options are set in the current-day economic realities of these farmers. Often, researchers spend a lot of time understanding the biophysical constraints on a system but neglect the linked socio-economic system in which farmers operate. To bring about change in how this pest is managed in the future, we need to assess both systems at the same time.

\section{Conclusions}

Given the right combination of environmental factors, many species of $B$. tabaci within the complex have the potential to become a pest at any one point in time and exhibit outbreaks in certain locations. Furthermore, these critical factors may vary from country to country and even region to region across East Africa. Our challenge is greater than just identifying factors; we must go one step further and identify which factors are the most important for smallholder farmers to manage to minimize the risk of outbreaks. This review represents a comprehensive summary of the knowledge to date, and should be used to guide future research questions by scientists all over the world addressing this challenge.

\section{Acknowledgements}

The authorship list is made up of members of the African Cassava Whitefly Project (ACWP) team (http://cassavawhitefly.org/people) who made a significant contribution to the writing of this manuscript; however, all members of the team contributed thoughts, discussion and ideas. The authors thank them for their contribution. Hazel Parry and Paul Mwebaze helpfully reviewed an early version of this manuscript. This work was supported by the Natural Resources Institute, University of Greenwich from a grant provided by the Bill \& Melinda Gates foundation (Grant Agreement OPP1058938). Mark Parnell (NRI) was very helpful in facilitating this work and the broader project goals.

\section{References}

Adriko, J., Sserubombwe, W.S., Adipala, E., Bua, A., Thresh, J. M. \& Edema, R. (2011) Response of improved cassava varieties in Uganda to cassava mosaic disease (CMD) and their inherent resistance mechanisms. African Journal of Agricultural Research 6, 521-531.

Alabi, O.J., Ogbe, F.O., Bandyopadhyay, R., Kumar, P.L., Dixon, A.G.O., Hughes, J. \& Naidu, R.A. (2008) Alternate hosts of African cassava mosaic virus and East African cassava mosaic Cameroon virus in Nigeria. Archives of Virology 153, 1743-1747. doi: 10.1007/s00705-008-0169-8.

Alicai, T., Omongo, C.A., Maruthi, M.N., Hillocks, R.J., Baguma, Y., Kawuki, R., Bua, A., Otim-Nape, G.W. \& Colvin, J. (2007) Re-emergence of cassava brown streak disease in Uganda. Plant Disease 91, 24-29. doi: 10.1094/pd-91-0024.

Alicai, T., Ndunguru, J., Sseruwagi, P., Tairo, F., Okao-Okuja, G., Nanvubya, R., Kiiza, L., Kubatko, L., Kehoe, M.A. \& Boykin, L.M. (2016) Cassava brown streak virus has a rapidly evolving genome: implications for virus speciation, variability, diagnosis and host resistance. Scientific Reports 6, 36164. doi: 10.1038 /srep36164.

Antony, B., Lisha, V.S., Palaniswami, M.S., Sugunan, V.S., Makeshkumar, T. \& Henneberry, T.J. (2006) Bemisia tabaci (Homoptera : Aleyrodidae) and Indian cassava mosaic virus transmission. International Journal of Tropical Insect Science 26, 176-182. doi: 10.1079/ijt2006110.

Asiimwe, P., Ecaat, J.S., Guershon, M., Kyamanywa, S., Gerling, D. \& Legg, J.P. (2007a) Evaluation of Serangium n. sp (Col., Coccinellidae), a predator of Bemisia tabaci (Hom., Aleyrodidae) on cassava. Journal of Applied Entomology 131, 76-80. doi: 10.1111/j.1439-0418.2006.01122.x.

Asiimwe, P., Ecaat, J.S., Otim, M., Gerling, D., Kyamanywa, S. \& Legg, J.P. (2007b) Life-table analysis of mortality factors 
affecting populations of Bemisia tabaci on cassava in Uganda. Entomologia Experimentalis Et Applicata 122, 37-44. doi: 10.1111/j.1570-7458.2006.00487.x.

Barbosa, L., Yuki, V.A., Marubayashi, J.M., De Marchi, B.R., Perini, F.L., Pavan, M.A., de Barros, D.R., Ghanim, M., Moriones, E., Navas-Castillo, J. \& Krasue-Sakate, R. (2015) First report of Bemisia tabaci Mediterranean (Q Biotype) species in Brazil. Pest Management Science 71(4), 501-504. doi: 10.1002/ps.3909.

Bellotti, A., Peña, J., Arias, B., Guerrero, J.M., Trujillo, H., Holguín, C. \& Ortega, A. (2005) Biological control of whiteflies by indigenous natural enemies for major food crops in the Neotropics. pp. 313-323 in Anderson, P.K. \& Morales F.J. (Eds) Whitefly and Whitefly-Borne Viruses in the Tropics: Building A Knowledge Base for Global Action. Colombia, International Centre for Tropical Agriculture.

Berlinger, M.J., Lehmann-Sigura, N. \& Taylor, R.A.J. (1996) Survival of Bemisia tabaci adults under different climatic conditions. Entomologia Experimentalis Et Applicata 80, 511-519.

Bigirimana, S., Barumbanze, P., Ndayihanzamaso, P., Shirima, R., \& Legg, J.P., (2011) First report of cassava brown streak disease and associated Ugandan cassava brown streak virus in Burundi. New Disease Reports 24, 2044-0588.

Blagbrough, I.S., Bayoumi, S.A.L., Rowan, M.G. \& Beeching, J. R. (2010) Cassava: an appraisal of its phytochemistry and its biotechnological prospects. Phytochemistry 71, 1940-1951. doi: 10.1016/j.phytochem.2010.09.001.

Bouwmeester, H., Heuvelink, G.B.M., Legg, J.P. \& Stoorvogel, J. J. (2012) Comparison of disease patterns assessed by three independent surveys of cassava mosaic virus disease in Rwanda and Burundi: comparison of crop virus disease patterns in Rwanda and Burundi. Plant Pathology 61,399-412. doi: 10.1111/j.1365-3059.2011.02500.x.

Boykin, L.M. \& De Barro, P. (2014) A practical guide to identifying members of the Bemisia tabaci species complex: and other morphologically identical species. Frontiers in Ecology and Evolution 2, doi: 10.3389/fevo.2014.00045.

Boykin, L.M., Shatters, R.G. Jr., Rosell, R.C., McKenzie, C.L., Bagnall, R.A., De Barro, P.J. \& Frohlich, D.R. (2007) Global relationships of Bemisia tabaci (Hemiptera: Aleyrodidae) revealed using Bayesian analysis of mitochondrial COI DNA sequence. Molecular Phylogenetics and Evolution 44, 1306-1319.

Boykin, L.M., Armstrong, K.F., Kubatko, L. \& De Barro, P.J. (2012) Species delimitation and global biosecurity. Evolutionary Bioinformatics 8, 1-37.

Boykin, L.M., Bell, C.D., Evans, G., Small, I. \& De Barro, P.J. (2013) Is agriculture driving the diversification of the Bemisia tabaci species complex (Hemiptera: Sternorrhyncha: Aleyrodidae)? Dating, diversification and biogeographic evidence revealed. BMC Evolutionary Biology 13, 228. doi: 10.1186/1471-2148-13-228.

Boykin, L.M., Kinene, T., Wainaina, J., Seal, S., Mugerwa, H., Macfadyen, S., De Barro, P., Tay, W.T., Kubatko, L., Alicai, T., Omongo, C.A., Tairo, F., Ndunguru, J. \& Sseruwagi, P. (2018) Review and future guide to the naming system of African Bemisia tabaci species. Systematic Entomology. Accepted January 2018.

Burban, C., Fishpool, L.D.C., Fauquet, C., Fargette, D. \& Thouvenel, J.C. (1992) Host-associated biotypes within West African populations of the whitefly Bemisia tabaci (Genn), (Hom, Aleyrodidae). Journal of Applied Entomology 113, 416-423.

Caciagli, P. (2007) Survival of whiteflies during long-distance transportation of agricultural products. in Czosnek, H. (ed.) Tomato Yellow Leaf Curl Virus Disease Management, Molecular Biology, Breeding for Resistance. Dordrecht, Springer.
Calatayud, P.A., Rahbé, Y., Delobel, B., Khuong-Huu, F., Tertuliano, M. \& Le Rü, B. (1994a) Influence of secondary compounds in the phloem sap of cassava on expression of antibiosis towards the mealybug Phenacoccus manihoti. Entomologia Experimentalis et Applicata 72, 47-57. doi: 10.1111/j.1570-7458.1994.tb01801.x.

Calatayud, P.A., Rahbé, Y., Tjallingii, W.F., Tertuliano, M. \& Le Rü, B. (1994b) Electrically recorded feeding behaviour of cassava mealybug on host and non-host plants. Entomologia Experimentalis et Applicata 72, 219-232. doi: 10.1111/j.15707458.1994.tb01821.x.

Calatayud, P.A., Rouland, C. \& Le Rü, B. (1997) Influence de la linamarine dans la relation manioc-cochenille. Acta Botanica Gallica 144, 427-432. doi: 10.1080/12538078.1997.10515782.

Calvo, F., Bolckmans, K. \& Belda, J. (2012) Release rate for a pre-plant application of Nesidiocoris tenuis for Bemisia tabaci control in tomato. Biocontrol 57, 809-817.

Chikoti, P.C., Ndunguru, J., Melis, R., Tairo, F., Shanahan, P. \& Sseruwagi, P. (2013) Cassava mosaic disease and associated viruses in Zambia: occurrence and distribution. International Journal of Pest Management 59, 63-72. doi: 10.1080/ 09670874.2012.752887.

Colvin, J., Fishpool, L.D.C., Fargette, D., Sherington, J. \& Fauquet, C. (1998) Bemisia tabaci (Hemiptera: Aleyrodidae) trap catches in a cassava field in cote d'Ivoire in relation to environmental factors and the distribution of African cassava mosaic disease. Bulletin of Entomological Research 88, 369-378.

Colvin, J., Otim-Nape, G.W., Holt, J., Omongo, C., Seal, S., Stevenson, P.C., Cooter, R.J. \& Thresh, J.M. (1999) Factors driving the current epidemic of severe cassava mosaic disease in East Africa. pp. 76-77 in VIIth International Plant Virus Epidemiology Symposium-Plant Virus Epidemiology: Current Status and Future Prospects, Aguadulce. Almeria, Spain, International Society of Plant Pathology.

Colvin, J., Omongo, C.A., Maruthi, M.N., Otim-Nape, G.W. \& Thresh, J.M. (2004) Dual begomovirus infections and high Bemisia tabaci populations: two factors driving the spread of a cassava mosaic disease pandemic. Plant Pathology 53, 577584. doi: $10.1111 /$ j.1365-3059.2004.01062.x.

Colvin, J., Omongo, C.A., Govindappa, M.R., Stevenson, P.C., Maruthi, M.N., Gibson, G., Seal, S.E., Muniyappa, V. (2006) Host-plant viral infection effects on arthropod-vector population growth, development and behaviour: management and epidemiological implications. Advances in Virus Research 67, 419-452. doi: 10.1016/s0065-3527(06)67011-5.

Cours, G., Fargette, D., Otim-Nape, G.W. \& Thresh, J.M. (1997) The epidemic of cassava mosaic virus disease in Madagascar in the 1930s-1940s: lessons for the current situation in Uganda. Tropical Science 37, 238-248.

Crowder, D.W., Ellers-Kirk, C., Yafuso, C.M., Dennehy, T.J. Degain, B.A., Harpold, V.S., Tabashnik, B.E. \& Carrière, Y. (2008) Inheritance of resistance to Pyriproxyfen in Bemisia tabaci (Hemiptera: Aleyrodidae) males and females (B biotype). Journal of Economic Entomology 101, 927-932. doi: 10.1603/0022-0493(2008)101[927:IORTPI]2.0.CO;2.

De Barro, P. (2012) Getting the Most out of Eretmocerus Hayati, an Effective Natural Enemy of Silverleaf Whitefly. Horticulture Australia Ltd, Final Report VG08051, Elizabeth Street Sydney NSW, Australia.

de Bon, H., Huat, J., Parrot, L., Sinzogan, A., Martin, T., Malézieux, E. \& Vayssières, J.F. (2014) Pesticide risks from fruit and vegetable pest management by small farmers in sub-Saharan Africa. A review. Agronomy for Sustainable Development 34, 723-736. doi: 10.1007/s13593-014-0216-7. 
Delatte, H., Holota, H., Warren, B.H., Becker, N., Thierry, M. \& Reynaud, B. (2011) Genetic diversity, geographical range and origin of Bemisia tabaci biotype Ms. Bulletin of Entomological Research 101, 487-497.

Drost, Y.C., van Lenteren, J.C. \& van Roermund, H.J.W. (1988) Life-history parameters of different biotypes of Bemisia tabaci (Hemiptera: Aleyrodidae) in relation to temperature and host plant: a selective review. Bulletin of Entomological Research 88(3), 219-229.

Dubern, J. (1994) Transmission of African cassava mosaic geminivirus by the whitefly Bemisia tabaci. Tropical Science 34, 82-91.

Elbadry, E.A. (1968) Biological studies on Amblyseius aleyrodis a predator of the cotton whitefly (Acarina, Phytoseiidae). Entomophaga 13, 323-329. doi: 10.1007/BF02371914.

Fargette, D., Fauquet, C, \& Thouvenel, J. (1985). Field studies on the spread of African Cassava Mosaic. Annals of Applied Biology 106(2), 285-294. doi: 10.1111/j.1744-7348.1985. tb03118.x.

Fargette, D., Fauquet, C. \& Thouvenel, J. (1988) Yield losses induced by African cassava mosaic virus in relation to the mode and the date of infection. Tropical Pest Management 34, 89-91. doi: 10.1080/09670878809371216.

Fargette, D., Fauquet, C., Grenier, E. \& Thresh, J.M. (1990) The spread of African cassava mosaic virus into and within cassava fields. Journal of Phytopathology-Phytopathologische Zeitschrift 130, 289-302. doi: 10.1111/j.1439-0434.1990. tb01179.x.

Fargette, D., Jeger, M., Fauquet, C. \& Fishpool, L.D.C. (1993) Analysis of temporal disease progress of African cassava mosaic-virus. Phytopathology 84, 91-98. doi: 10.1094/ Phyto-84-91.

Fauquet, C. \& Fargette, D. (1990) African cassava mosaic, virus, etiology, epidemiology, and control. Plant Disease 74, 404411. doi: 10.1094/pd-74-0404.

Fauquet, C., Fargette, D. \& Thouvenel, J.C. (1988) Some aspects of the epidemiology of African cassava mosaic virus in Ivory Coast. Tropical Pest Management 34, 92-96. doi: 10.1080/ 09670878809371217

Fishpool, L.D.C. \& Burban, C. (1994) Bemisia tabaci: the whitefly vector of African cassava mosaic geminivirus. Tropical Science $34,55-72$.

Fishpool, L.D.C., Fauquet, C., Fargette, D., Thouvenel, J.C., Burban, C. \& Colvin, J. (1995) The phenology of Bemisia tabaci (Homoptera: Aleyrodidae) populations on cassava in southern Côte d'Ivoire. Bulletin of Entomological Research 85, 197-207. doi: 10.1017/S0007485300034271.

Gerling, D., Horowitz, A.R. \& Baumgaertner, J. (1986) Autoecology of Bemisia tabaci. Agriculture Ecosystems $\mathcal{E}$ Environment 17, 5-19. doi: 10.1016/0167-8809(86)90022-8.

Ghosh, S., Bouvaine, S. \& Maruthi, M. (2015) Prevalence and genetic diversity of endosymbiotic bacteria infecting cassava whiteflies in Africa. BMC Microbiology 15 doi: 10.1186/ s12866-015-0425-5.

Gibson, R.W. \& Otim-Nape, G.W. (1997) Factors determining recovery and reversion in mosaic-affected African cassava mosaic virus resistant cassava. Annals of Applied Biology 131, 259-271. doi: 10.1111/j.1744-7348.1997.tb05155.x.

Gibson, R.W., Legg, J.P. \& Otim-Nape, G.W. (1996) Unusually severe symptoms are a characteristic of the current epidemic of mosaic virus disease of cassava in Uganda. Annals of Applied Biology 128, 479-490. doi: 10.1111/j.1744-7348.1996.tb07108.x.

Gnankine, O., Ketoh, G. \& Martin, T. (2013) Dynamics of the invasive Bemisia tabaci (Homoptera: Aleyrodidae) Mediterranean (MED) species in two West African countries.
International Journal of Tropical Insect Science 33, 99-106. doi: $10.1017 /$ S1742758413000040.

Gold, C.S., Altieri, M.A. \& Bellotti, A.C. (1989) The effects of intercropping and mixed varieties of predators and parasitoids of cassava whiteflies (Hemiptera, Aleyrodidae) in Colombia. Bulletin of Entomological Research 79, 115-121.

Gottlieb, Y., Zchori-Fein, E., Mozes-Daube, N., Kontsedalov, S., Skaljac, M., Brumin, M., Sobol, I., Czosnek, H., Vavre, F., Fleury, F. \& Ghanim, M. (2010) The transmission efficiency of tomato yellow leaf curl virus by the whitefly Bemisia tabaci Is correlated with the presence of a specific symbiotic bacterium species. Journal of Virology 84, 9310-9317. doi: 10.1128/JVI.00423-10.

Gregory, P.H. (1948) The multiple-infection transformation Annals of Applied Biology 35, 412-417.

Guastella, D., Lulah, H., Tajebe, L.S., Cavalieri, V., Evans, G.A., Pedata, P.A., Rapisarda, C. \& Legg, J.P. (2015) Survey on whiteflies and their parasitoids in cassava mosaic pandemic areas of Tanzania using morphological and molecular techniques. Pest Management Science 71, 383-394. doi: 10.1002/ ps.3810.

Gunning, R.V., Byrne, F.J., Condé, B.D., Connelly, M.I., Hergstrom, K. \& Devonshire, A.L. (1995) First report of B-biotype Bemisia tabaci (Hennadius) (Hemiptera: Aleyrodidae) in Australia. Australian Journal of Entomology 34, 116-116. doi: 10.1111/j.1440-6055.1995.tb01298.x.

Harrison, B.D., Zhou, X., Otim-Nape, G.W., Liu, Y. \& Robinson, D.J. (1997) Role of a novel type of double infection in the geminivirus-induced epidemic of severe cassava mosaic in Uganda. Annals of Applied Biology 131, 437-448. doi: 10.1111/ j.1744-7348.1997.tb05171.x.

Hillocks, R.J. \& Jennings, D.L. (2003) Cassava brown streak disease: a review of present knowledge and research needs. International Journal of Pest Management 49, 225-234. doi: 10.1080/0967087031000101061.

Himler, A.G., Adachi-Hagimori, T., Bergen, J.E., Kozuch, A., Kelly, S.E., Tabashnik, B.E., Chiel, E., Duckworth, V.E., Dennehy, T.J., Zchori-Fein, E. \& Hunter, M.S. (2011) Rapid spread of a bacterial symbiont in an invasive whitefly is driven by fitness benefits and female bias. Science 332, 254256. doi: $10.1126 /$ science. 1199410 .

Hoelmer, K., Gerling, D. \& Mayer, R.T. (1995) Whitefly Parasitoids: Can They Control Field Populations of Bemisia? England, Intercept Andover.

Holt, J. \& Colvin, J. (2001) Observation and theory of whitefly-borne virus disease epidemics. pp. 331-343 in Edited for the British Society for Plant Pathology by Jeger, M.J. \& Spence, N.J. (Eds) Biotic Interactions in Plant-Pathogen Associations. Wallingford, Oxon, UK, CABI publishing. ISBN no s 0851995128.

Horowitz, A.R. \& Ishaaya, I. (2014) Dynamics of biotypes B and Q of the whitefly Bemisia tabaci and its impact on insecticide resistance. Pest Management Science 70, 1568-1572. doi: $10.1002 /$ ps.3752.

Jameson, J.D. (1964) Cassava mosaic disease in Uganda. East African Agricultural and Forestry Journal 29, 208-213. doi: 10.1080/00128325.1964.11661927.

Jeremiah, S.C., Ndyetabula, I.L., Mkamilo, G.S., Haji, S., Muhanna, M.M., Chuwa, C., Kasele, S., Bouwmeester, H., Ijumba, J.N. \& Legg, J.P. (2015) The dynamics and environmental influence on interactions between cassava brown streak disease and the whitefly, Bemisia tabaci. Phytopathology 105, 646-655. doi: 10.1094/PHYTO-05-14-0146-R.

Katono, K., Alicai, T., Baguma, Y., Edema, R., Bua, A. \& Omongo, C. (2015) Influence of host plant resistance and 
disease pressure on spread of cassava brown streak disease in Uganda. American Journal of Experimental Agriculture 7, 284293. doi: 10.9734/AJEA/2015/15563.

Kliot, A., Cilia, M., Czosnek, H. \& Ghanim, M. (2014) Implication of the bacterial endosymbiont Rickettsia spp. in interactions of the whitefly Bemisia tabaci with tomato yellow leaf curl virus. Journal of Virology 88, 5652-5660. doi: 10.1128/JVI.00071-14.

Kontsedalov, S., Zchori-Fein, E., Chiel, E., Gottlieb, Y., Inbar, M. \& Ghanim, M. (2008) The presence of rickettsia is associated with increased susceptibility of Bemisia tabaci (Homoptera: Aleyrodidae) to insecticides. Pest Management Science 64, 789782. doi: $10.1002 /$ ps.1595.

Kristensen, N.P., Schellhorn, N.A., Hulthen, A.D., Howie, L.J. \& De Barro, P.J. (2013) Wind-borne dispersal of a parasitoid: the process, the model, and its validation. Environmental Entomology 42, 1137-1148. doi: 10.1603/EN12243.

Laarif, A., Saleh, D., Clouet, C. \& Gauthier, N. (2015) Regional co-occurrence between distinct Bemisia tabaci species in Tunisia with new insights into the role of host plants. Phytoparasitica 43, 135-150. doi: 10.1007/s12600-014-0437-y.

Legg, J.P. (1994) Bemisia tabaci: the whitefly vector of cassava mosaic geminiviruses in Africa: an ecological perspective. African Crop Science Journal 2, 437-448.

Legg, J.P. (1995) The ecology of Bemisia tabaci (Gennadius) (Homoptera), vector of African cassava mosaic geminivirus in Uganda. PhD, University of Reading, UK.

Legg, J.P. (1999) Emergence, spread and strategies for controlling the pandemic of cassava mosaic virus disease in east and Central Africa. Crop Protection 18, 627-637. doi: 10.1016/ S0261-2194(99)00062-9.

Legg, J.P. \& Hillocks, R.J. (2003) Cassava brown streak virus disease; past present and future. pp. 89 in Legg, J.P. \& Hillocks, R.J. (Eds) Proceedings of an International Workshop, Mombasa, Kenya, 27-30 October 2002. Aylesford, UK, Natural Resources International Limited.

Legg, J.P. \& Ogwal, S. (1998) Changes in the incidence of African cassava mosaic virus disease and the abundance of its whitefly vector along south-north transects in Uganda. Journal of Applied Entomology-Zeitschrift Fur Angewandte Entomologie 122, 169-178.

Legg, J.P. \& Raya, M.D. (1998) Survey of cassava virus diseases in Tanzania. International Journal of Pest Management 44, 17-23.

Legg, J.P. \& Thresh, J.M. (2000) Cassava mosaic virus disease in East Africa: a dynamic disease in a changing environment. Virus Research 71, 135-149. doi: 10.1016/S0168-1702(00) 00194-5.

Legg, J.P., French, R., Rogan, D., Okao-Okuja, G. \& Brown, J.K. (2002) A distinct Bemisia tabaci (Gennadius) (Hemiptera: Sternorrhyncha: Aleyrodidae) genotype cluster is associated with the epidemic of severe cassava mosaic virus disease in Uganda. Molecular Ecology 11, 1219-1229.

Legg, J., Gerling, D. \& Neuenschwander, P. (2003) Biological control of whiteflies in sub-Saharan Africa. pp. 87-100 in Neuenschwander, P. \& Langewald, J. (Eds) Biological Control in IPM Systems in Africa. Wallingford, UK, CAB International.

Legg, J., Owor, B., Sseruwagi, P. \& Ndunguru, J. (2006) Cassava mosaic virus disease in East and Central Africa: epidemiology and management of a regional pandemic. Advances in Virus Research 67, 355-418.

Legg, J.P., Jeremiah, S.C., Obiero, H.M., Maruthi, M.N., Ndyetabula, I., Okao-Okuja, G., Bouwmeester, H., Bigirimana, S., Tata-Hangy, W., Gashaka, G., Mkamilo, G., Alicai, T. \& Kumar, P.L. (2011) Comparing the regional epidemiology of the cassava mosaic and cassava brown streak virus pandemics in Africa. Virus Research 159, 161-170. doi: 10.1016/j.virusres.2011.04.018.

Legg, J.P., Sseruwagi, P., Boniface, S., Okao-Okuja, G., Shirima, R., Bigirimana, S., Gashaka, G., Herrmann, H.W., Jeremiah, S., Obiero, H., Ndyetabula, I., Tata-Hangy, W., Masembe, C. \& Brown, J.K. (2014a) Spatio-temporal patterns of genetic change amongst populations of cassava Bemisia tabaci whiteflies driving virus pandemics in East and Central Africa. Virus Research 186, 61-75. doi: 10.1016/j.virusres.2013.11.018.

Legg, J.P., Shirima, R., Tajebe, L.S., Guastella, D., Boniface, S., Jeremiah, S., Nsami, E., Chikoti, P. \& Rapisarda, C. (2014b) Biology and management of Bemisia whitefly vectors of cassava virus pandemics in Africa. Pest Management Science 70, 1446-1453. doi: 10.1002/ps.3793.

Legg, J.P., Lava Kumar, P., Makeshkumar, T., Tripathi, L., Ferguson, M., Kanju, E., Ntawuruhunga, P. \& Cuellar, W. (2015) Cassava virus diseases. Advances in Virus Research 91, $85-42$.

Leuschner, K. (1977) Whiteflies: biology and transmission of African mosaic disease. pp. 51-58 in Brekelbaum, T., Bellotti, A. \& Lozano, C.J. (Eds) Proceedings of the Cassava Protection Workshop, CIAT, 7-12 November, 1977 Cali. Colombia, The International Center for Tropical Agriculture.

Liu, S.S., Colvin, J. \& De Barro, P. (2012) Species concepts as applied to Bemisia tabaci systematics: how many species are there? Journal of Integrative Agriculture 11, 176-186.

Mabasa, K.G. (2007) Epidemiology of Cassava Mosaic Disease and Molecular Characterization of Cassava Mosaic Viruses and Their Associated Whitefly (Bemisia tabaci) Vector in South Africa. Johannesburg, University of the Witwatersrand.

Manani, D.M., Ateka, E.M., Nyanjom, S.R.G. \& Boykin, L.M. (2017) Phylogenetic relationships among whiteflies in the Bemisia tabaci (Gennadius) species complex from major cassava growing areas in Kenya. Insects 8, 1-14. doi: 10.3390/ insects8010025.

Maruthi, M.N., Colvin, J., Seal, S. \& Thresh, J.M. (2002a). First report of a distinct begomovirus infecting cassava from Zanzibar. Plant Disease 86, 187.

Maruthi, M.N., Colvin, J., Seal, S., Gibson, G. \& Cooper, J. (2002b) Co-adaptation between cassava mosaic geminiviruses and their local vector populations. Virus Research 86, 71-85. doi: 10.1016/s0168-1702(02)00051-5.

Maruthi, M.N., Hillocks, R.J., Mtunda, K., Raya, M.D., Muhanna, M., Kiozia, H., Rekha, A.R., Colvin, J. \& Thresh, J.M. (2005) Transmission of cassava brown streak virus by Bemisia tabaci (Gennadius). Journal of Phytopathology 153, 307312. doi: 10.1111/j.1439-0434.2005.00974.x.

Mbewe, W., Kumar, P.L., Changadeya, W., Ntawuruhunga, P. \& Legg, J. (2015) Diversity, distribution and effects on cassava cultivars of cassava brown streak viruses in Malawi. Journal of Phytopathology 163, 433-443. doi: 10.1111/jph.12339.

McGrath, P.F. \& Harrison, B.D. (1995) Transmission of tomato leaf curl geminiviruses by Bemisia tabaci: effects of virus isolate and vector biotype. Annals of Applied Biology 126, 307316. doi: 10.1111/j.1744-7348.1995.tb05368.x.

McMeniman, C.J. \& O'Neill, S.L. (2010) A virulent Wolbachia infection decreases the viability of the dengue vector Aedes aegypti during periods of embryonic quiescence (C-C Chen, Ed.). PLoS Neglected Tropical Diseases 4, e748. doi: 10.1371/ journal.pntd.0000748.

McQuaid, C.F., van den Bosch, F., Szyniszewska, A., Alicai, T., Pariyo, A., Chikoti, P.C. \& Gilligan, C.A. (2017) Spatial dynamics and control of a crop pathogen with mixed-mode transmission. PLoS Computational Biology 13, e1005654. 
Meyerdirk, D.E. \& Coudriet, D.L. (1985) Predation and developmental studies of Euseius hibisci (Chant) (Acarina, Phytoseiidae) feeding on Bemisia tabaci (Gennadius) (Homoptera, Aleyrodidae). Environmental Entomology 14, 24-27.

Mohammed, I.U., Ghosh, S. \& Maruthi, M.N. (2016) Host and virus effects on reversion in cassava affected by cassava brown streak disease. Plant Pathology 65, 593-600. doi: 10.1111/ppa.12458.

Morales, F.J. \& Jones, P.G. (2004) The ecology and epidemiology of whitefly-transmitted viruses in Latin America. Virus Research 100, 57-65. doi: 10.1016/j.virusres.2003.12.014.

Mugerwa, H., Rey, M.E., Alicai, T., Ateka, E., Atuncha, H., Ndunguru, J. \& Sseruwagi, P. (2012) Genetic diversity and geographic distribution of Bemisia tabaci (Gennadius) (Hemiptera: Aleyrodidae) genotypes associated with cassava in East Africa. Ecol Evol 2, 2749-2762. doi: 10.1002/ece3.379.

Muimba-Kankolongo, A., Chalwe, A., Sisupo, P. \& Kang, M. (1997) Distribution, prevalence and outlook for control of cassava mosaic disease in Zambia. Roots 4, 2-7.

Muli, E., Patch, H., Frazier, M., Frazier, J., Torto, B., Baumgarten, T., Kilonzo, J., Kimani, J.N., Mumoki, F., Masiga, D., Tumlinson, J. \& Grozinger, C. (2014) Evaluation of the distribution and impacts of parasites, pathogens, and pesticides on honey bee (Apis mellifera) populations in East Africa. PLoS ONE 9, e94459. doi: 10.1371/journal.pone.0094459.

Ndunguru, J., Sseruwagi, P., Tairo, F., Stomeo, F., Maina, S., Djikeng, A., Kehoe, M. \& Boykin, L.M. (2015) Analyses of twelve new whole genome sequences of cassava brown streak viruses and Ugandan cassava brown streak viruses from east Africa: diversity, supercomputing and evidence for further speciation. PLOS ONE 10, E0139321.

Nelson, S. (2008) Sooty Mold. Plant Disease PD-52. Mänoa, Honolulu, Hawai'i, Cooperative extension Service, College of Tropical Agriculture and Human Resources, University of Hawaii.

Nichols, R.F. (1950) The brown streak disease of cassava distribution climatic effects and diagnostic symptoms. The East African Agricultural Journal 15, 154-160.

Night, G., Asiimwe, P., Gashaka, G., Nkezabahizi, D., Legg, J.P., Okao-Okuja, G., Obonyo, R., Nyirahorana, C., Mukakanyana, C., Mukase, F., Munyabarenzi, I. \& Mutumwinka, M. (2011) Occurrence and distribution of cassava pests and diseases in Rwanda. Agriculture Ecosystems \& Environment 140, 492-497. doi: 10.1016/j.agee.2011.01.014.

Ntawuruhunga, P. \& Legg, J. (2007) New Spread of Cassava Brown Streak Virus Disease and its Implications for the Movement of Cassava Germplasm in the East and Central African Region. International Institute of Tropical Agriculture-Uganda \& Eastern Africa Root Crops Research Network, Kampala, Uganda. Network Report.

Oliveira, M.R.V., Henneberry, T.J. \& Anderson, P. (2001) History, current status, and collaborative research projects for Bemisia tabaci. Crop Protection 20, 709-723.

Omongo, C.A. (2003) Cassava whitefly, Bemesia tabaci, behaviour and ecology in relation to the spread of the cassava mosaic epidemic in Uganda. PhD, University of Greenwich, UK.

Omongo, C.A., Kawuki, R., Bellotti, A.C., Alicai, T., Baguma, Y., Maruthi, M.N., Bua, A. \& Colvin, J. (2012) African cassava whitefly, Bemisia tabaci, resistance in African and South American cassava genotypes. Journal of Integrative Agriculture 11, 327-336. doi: 10.1016/s2095-3119(12)60017-3.

Otim, M., Legg, J., Kyamanywa, S., Polaszek, A. \& Gerling, D. (2005) Occurrence and activity of Bemisia tabaci parasitoids on cassava in different agro-ecologies in Uganda. Biocontrol 50, 87-95. doi: 10.1007/s10526-004-0822-4.
Otim, M., Legg, D.J., Kyamanywa, S., Polaszek, A. \& Gerling, D. (2006) Population dynamics of Bemisia tabaci (Homoptera: Aleyrodidae) parasitoids on cassava mosaic disease-resistant and susceptible varieties. Biocontrol Science and Technology 16, 205-214. doi: 10.1080/09583150500335558.

Otim, M., Kyalo, G., Kyamanywa, S., Asiimwe, P., Legg, J.P., Guershon, M. \& Gerling, D. (2008) Parasitism of Bemisia tabaci (Homoptera: Aleyrodidae) by Eretmocerus mundus (Hymenoptera: Aphelinidae) on cassava. International Journal of Tropical Insect Science 28, 158. doi: 10.1017/ s1742758408093181.

Otim-Nape, G.W. \& Ingroot, D. (1986) Effect of cultural practices on the African cassava mosaic disease and its vector. pp. 105108 in Terry, E.R., Akoroda, M.O. \& Arene, O.B. (Eds) Proceedings of the Third Triennial Symposium of the International Society for Tropical Root Crops, Owerri, Nigeria 17-23 August 1986. IDRC 258E. Owerri, Nigeria, Ottawa International Development Research Centre.

Otim-Nape, G.W., Thresh, J.M. \& Fargette, D. (1995) Bemisia tabaci and cassava mosaic virus disease in Africa. pp. 319-350 in Gerling, D. \& Mayer, R.T. Bemisia 1995: Taxonomy, Biology, Damage, Control and Management. Andover, England, Intercept Ltd.

Otim-Nape, G.W., Thresh, J.M. \& Shaw, M.W. (1998) The incidence and severity of cassava mosaic virus disease in Uganda: 1990-92. Tropical Science 38, 25-37.

Otim-Nape, G.W., Bua, A., Thresh, J.M., Baguma, Y., Ogwal, S., Ssemakula, G.N., Acola, G., Byabakama, B., Colvin, J., Cooter, R.J. \& Martin, A. (2000) The Current Pandemic of Cassava Mosaic Virus Disease in East Africa and its Control. Chatham, UK, Natural Resources Institute Catalogue Services No. PSTC28, University of Greenwich.

Otim-Nape, G.W., Alicai, T. \& Thresh, J.M. (2001) Changes in the incidence and severity of cassava mosaic virus disease, varietal diversity and cassava production in Uganda. Annals of Applied Biology 138, 313-327.

Patil, B.L. \& Fauquet, C.M. (2010) Differential interaction between cassava mosaic geminiviruses and geminivirus satellites. Journal of General Virology 91, 1871-1882. doi: 10.1099/ vir.0.019513-0.

Patil, B., Legg, J., Kanju, E. \& Fauquet, C. (2015) Cassava brown streak disease: a threat to food security in Africa. Journal of General Virology 96, 956-968.

Polston, J.E., De Barro, P. \& Boykin, L.M. (2014) Transmission specificities of plant viruses with the newly identified species of the Bemisia tabaci species complex. Pest Management Science 70, 1547-1552. doi: 10.1002/ps.3738.

Riis, L., Bellotti, A.C., Bonierbale, M. \& O'Brien, G.M. (2003) Cyanogenic potential in cassava and its influence on a generalist insect herbivore Cyrtomenus bergi (Hemiptera: Cydnidae). Journal of Economic Entomology 96, 1905-1914. doi: 10.1603/0022-0493-6.6.1905.

Robertson, I.A.D. (1987) The whitefly, Bemisia tabaci (Gennadius) as a vector of African cassava mosaic virus at the Kenya coast and ways in which the yield losses in cassava, Manihot esculenta Crantz caused by the virus can be reduced. Insect Science and its Application 8, 797-801.

Sequeira, R.V., Shields, A., Moore, A. \& De Barro, P. (2009) Inter-seasonal population dynamics and pest status of Bemisia tabaci (Gennadius) biotype B in an Australian cropping system. Bulletin of Entomological Research 99, 325. doi: 10.1017/S000748530800638X.

Sseruwagi, P. (2005) Molecular variability of cassava Bemisia tabaci and its effect on the epidemiology of cassava mosaic 
geminiviruses in Uganda. PhD Thesis, The University of Witwatersrand, Johannesburg, South Africa.

Sseruwagi, P., Otim-Nape, G.W., Osiru, D.S.O. \& Thresh, J.M. (2003) Influence of NPK fertiliser on populations of the whitefly vector and incidence of cassava mosaic virus disease. African Crop Science Journal 11, 171-179.

Sseruwagi, P., Sserubombwe, W.S., Legg, J.P., Ndunguru, J. \& Thresh, J.M. (2004) Methods of surveying the incidence and severity of cassava mosaic disease and whitefly vector populations on cassava in Africa: a review. Virus Research 100, 129-142. doi: 10.1016/j.virusres.2003.12.021.

Sseruwagi, P., Legg, J.P., Maruthi, M.N., Colvin, J., Rey, M.E.C. \& Brown, J.K. (2005) Genetic diversity of Bemisia tabaci (Gennadius) (Hemiptera: Aleyrodidae) populations and presence of the $B$ biotype and a non-B biotype that can induce silverleaf symptoms in squash, in Uganda. Annals of Applied Biology 147, 253-265. doi: 10.1111/j.1744-7348.2005.00026.x.

Sseruwagi, P., Maruthi, M.N., Colvin, J., Rey, M.E.C., Brown, J. K. \& Legg, J.P. (2006) Colonization of non-cassava plant species by cassava whiteflies (Bemisia tabaci) in Uganda. Entomologia Experimentalis et Applicata 119, 145-153.

Sseruwagi, P., Wainaina, J., Ndunguru, J., Tumuhimbise, R., Tairo, F., Guo, J., Vrielink, A., Blythe, A., Kinene, T., De Marchi, B., Kehoe, M.A., Tanz, S. \& Boykin, L.M. (2017) The first transcriptomes from field-collected individual whiteflies (Bemisia tabaci, Hemiptera: Aleyrodidae). Gates Open Research 1, 16 doi: 10.12688 /gatesopenres.12783.1.

Storey, H.H. \& Nichols, R.F.W. (1938) Studies of the mosaic of cassava. Annals of Applied Biology 25, 790-806.

Swanson, M.M. \& Harrison, B.D. (1994) Properties, relationships and distribution of cassava mosaic geminiviruses. Tropical Science 34, 15-25.

Tajebe, L.S., Boni, S.B., Guastella, D., Cavalieri, V., Lund, O.S., Rugumamu, C.P., Rapisarda, C. \& Legg, J.P. (2015) Abundance, diversity and geographic distribution of cassava mosaic disease pandemic-associated Bemisia tabaci in Tanzania. Journal of Applied Entomology 139, 627-637. doi: $10.1111 /$ jen.12197.
Tan, X-L., Wang, S., Ridsdill-Smith, J. \& Liu, T-X. (2014) Direct and indirect impacts of infestation of tomato plant by Myzus persicae (Hemiptera: Aphididae) on Bemisia tabaci (Hemiptera: Aleyrodidae). PLoS ONE 9, e94310. doi: 10.1371/journal.pone.0094310.

Thompson, W.M.O. (2000) Development, morphometrics and other biological characteristics of the whitefly Bemisia tabaci (Gennadius) on cassava. Insect Science and its Application 20, 251-258.

Thompson, W.M.O. (2011) Interaction of Bemisia tabaci with East African cassava mosaic virus-infected plants. pp. 107-119 in Thompson, W.M.O. (Ed.) The Whitefly, Bemisia tabaci (Homoptera: Aleyrodidae) Interaction with Geminivirus-Infected Host Plants. Netherlands, Springer. doi:10.1007/978-94-007-1524-0_6.

Thresh, J.M., Otim-Nape, G.W., Legg, J.P. \& Fargette, D. (1997) African cassava mosaic virus disease: the magnitude of the problem. African Journal of Root and Tuber Crops 2, 13.

Uzokwe, V.N.E., Mlay, D.P., Masunga, H.R., Kanju, E., Odeh, I. O.A. \& Onyeka, J. (2016) Combating viral mosaic disease of cassava in the Lake Zone of Tanzania by intercropping with legumes. Crop Protection 84, 69-80. doi: 10.1016/j. cropro.2016.02.013.

Wang, H-L., Yang, J., Boykin, L.M., Zhao, Q-Y., Wang, Y-J., Liu, S-S. \& Wang, X-W. (2014) Developing conversed microsatellite markers and their implications in evolutionary analysis of the Bemisia tabaci complex. Scientific Reports 4, 6351. doi: 10.1038/srep06351.

Xu, J., De Barro, P.J. \& Liu, S.S. (2010) Reproductive incompatibility among genetic groups of Bemisia tabaci supports the proposition that the whitefly is a cryptic species complex. Bulletin of Entomological Research 100, 359-366. doi: 10.1017/ S0007485310000015.

Zundel, C., Nagel, P., Hanna, R., Korner, F. \& Scheidegger, U. (2009) Environment and host-plant genotype effects on the seasonal dynamics of a predatory mite on cassava in subhumid tropical Africa. Agricultural and Forest Entomology 11, 321-331. doi: 10.1111/j.1461-9563.2009.00429.x. 